\title{
Volcanic ash supply to the surface ocean - remote sensing of biological responses and their wider biogeochemical significance
}

\author{
Thomas J. Browning ${ }^{1 *+}$, Katherine Stone ${ }^{1}$, Heather A. Bouman ${ }^{1}$, Tamsin A. Mather ${ }^{1}$, David M. Pyle ${ }^{1}$, \\ C. Mark Moore ${ }^{2}$ and Victor Martinez-Vicente ${ }^{3}$
}

${ }^{1}$ Department of Earth Sciences, University of Oxford, Oxford, UK

${ }^{2}$ Ocean and Earth Science, National Oceanography Centre Southampton, University of Southampton, Southampton, UK

${ }_{3}^{3}$ Plymouth Marine Laboratory, Plymouth, UK

Edited by:

Maeve Carroll Lohan, University of

Plymouth, UK

Reviewed by:

Kristen N. Buck, University of South

Florida, USA

Mukesh Gupta, Environment

Canada, Canada

*Correspondence:

Thomas J. Browning, GEOMAR Helmholtz Centre for Ocean

Research, Kiel, Wischhofstraße 1-3, Build. 12, D-24148 Kiel, Germany

e-mail: tbrowning@geomar.de

${ }^{\dagger}$ Present address:

Thomas J. Browning, GEOMAR

Helmholtz Centre for Ocean

Research, Kiel, Germany
Transient micronutrient enrichment of the surface ocean can enhance phytoplankton growth rates and alter microbial community structure with an ensuing spectrum of biogeochemical feedbacks. Strong phytoplankton responses to micronutrients supplied by volcanic ash have been reported recently. Here we: (i) synthesize findings from these recent studies; (ii) report the results of a new remote sensing study of ash fertilization; and (iii) calculate theoretical bounds of ash-fertilized carbon export. Our synthesis highlights that phytoplankton responses to ash do not always simply mimic that of iron amendment; the exact mechanisms for this are likely biogeochemically important but are not yet well understood. Inherent optical properties of ash-loaded seawater suggest rhyolitic ash biases routine satellite chlorophyll-a estimation upwards by more than an order of magnitude for waters with $<0.1 \mathrm{mg}$ chlorophyll-a $\mathrm{m}^{-3}$, and less than a factor of 2 for systems with $>0.5 \mathrm{mg}$ chlorophyll-a $\mathrm{m}^{-3}$. For this reason post-ash-deposition chlorophyll-a changes in oligotrophic waters detected via standard Case 1 (open ocean) algorithms should be interpreted with caution. Remote sensing analysis of historic events with a bias less than a factor of 2 provided limited stand-alone evidence for ash-fertilization. Confounding factors were poor coverage, incoherent ash dispersal, and ambiguity ascribing biomass changes to ash supply over other potential drivers. Using current estimates of iron release and carbon export efficiencies, uncertainty bounds of ash-fertilized carbon export for three events are presented. Patagonian iron supply to the Southern Ocean from volcanic eruptions is less than that of windblown dust on 1000 year timescales but can dominate supply at shorter timescales. Reducing uncertainties in remote sensing of phytoplankton response and nutrient release from ash are avenues for enabling assessment of the oceanic response to large-scale transient nutrient enrichment.

Keywords: phytoplankton, dust, iron, ocean color, MODIS, nutrient limitation, carbon cycle, inherent optical properties

\section{INTRODUCTION}

Phytoplankton photosynthesis couples atmospheric and marine biogeochemical cycles with resultant impacts on marine food webs and climate (Falkowski et al., 1998; Kump et al., 1999; Duffy and Stachowicz, 2006; Sarmiento and Gruber, 2006). There is currently much interest and effort in constraining the supply of micronutrients, particularly iron $(\mathrm{Fe})$, to marine phytoplankton (Henderson et al., 2007; Boyd and Ellwood, 2010), and resolving the biogeochemical implications of fertilization, i.e., relieving nutrient limitation (Cullen et al., 1992; Boyd et al., 2007; Moore et al., 2013). Volcanic eruptions have the potential to transiently eject thousands-to-millions of tons of fine-grained $\mathrm{Fe}$-containing material high into the atmosphere in an acidic environment (e.g., Mather et al., 2003; Mason et al., 2004). The low pH of the ash plume enhances dissolution of Fe-bearing silicate minerals within the ash particle matrix, generating Fe-rich solutions that can reprecipitate out onto the surface of ash particles as highly-soluble Fe chlorides, fluorides and sulfate salts (Delmelle et al., 2007; Duggen et al., 2010; Ayris and Delmelle, 2012). Explosive eruptions can inject this material into the upper troposphere and stratosphere (e.g., Baines and Sparks, 2005), where it may be transported to even the remotest of open ocean regions (e.g., Self, 2006). Rapid dissolution of Fe-bearing salts can then occur on timescales less than that of ash particle settling through the photic zone of the water column (Duggen et al., 2007; Censi et al., 2010; Olgun et al., 2011).

Anomalies in atmospheric $\mathrm{CO}_{2}$ and $\mathrm{O}_{2}$ records in the 1990s (Keeling and Shertz, 1992; Keeling et al., 1996) were speculated 


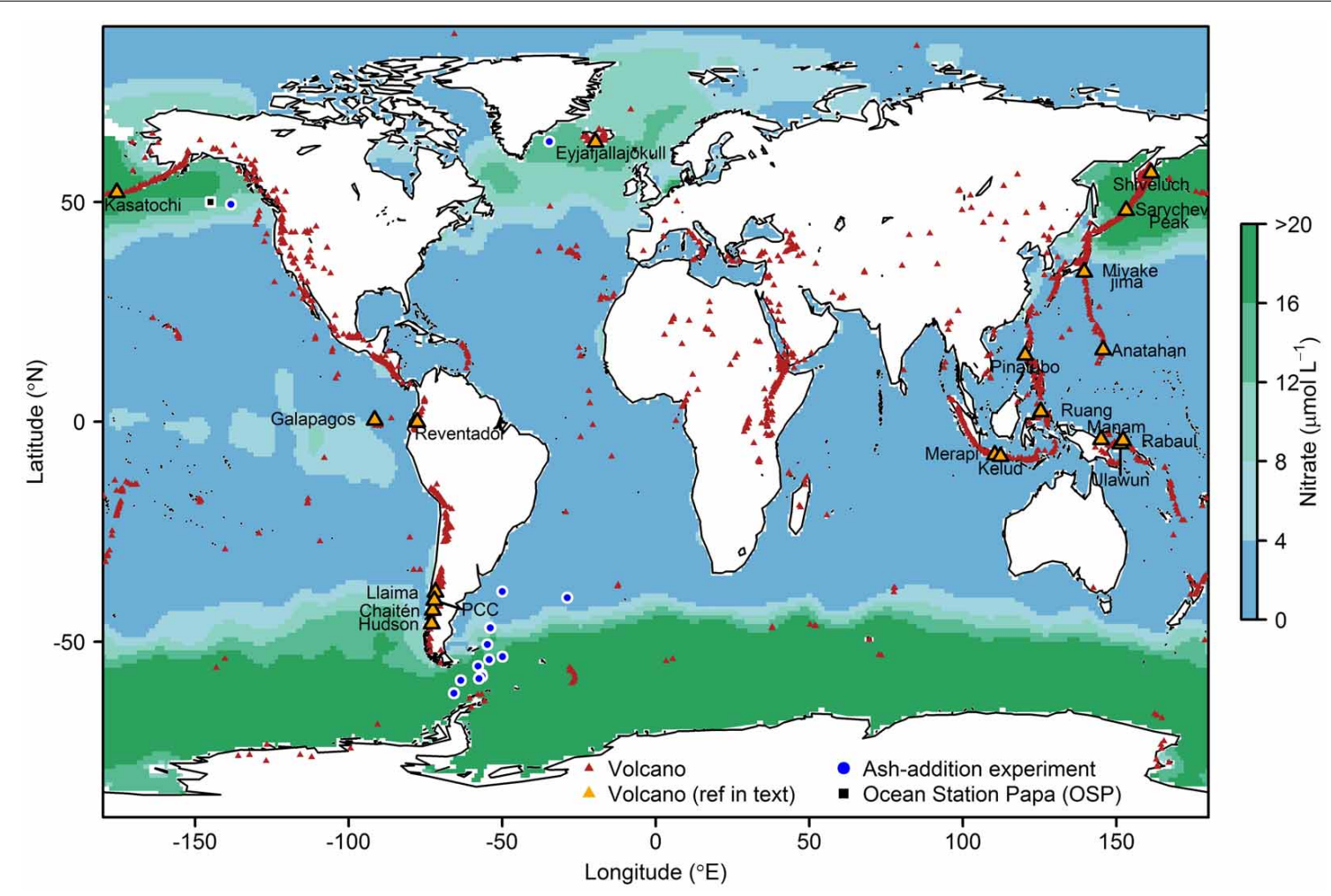

FIGURE 1 | Global surface ocean nitrate concentrations from the World Ocean Circulation Experiment (WOCE). Red triangles show the locations of volcanoes thought to have been active in the last 10,000 years (Global Volcanism Program, http://www.volcano.si.edu/ index.cfm), orange triangles $=$ those referred to in the main text and Table 3. The Sierra Negra and La Cumbre volcanoes referred to in the text are located in the Galapagos Islands. Also shown are sites of ash addition experiments (blue circles) performed in the North Atlantic (Achterberg et al., 2013), North Pacific (Mélançon et al., 2014) and South Atlantic and Southern Ocean (Browning et al., 2014a), and the location of Ocean Station Papa (OSP, black square). PCC, Puyehue-Cordón Caulle. to originate from large scale Fe fertilization of the remote highnitrate Southern Ocean after the eruption of Mt Pinatubo in 1991 (Figure 1; Sarmiento, 1993; Watson, 1997; after Spirakis, 1991). Unfortunately, whilst presenting an intriguing hypothesis, direct evidence for marine phytoplankton responding to ash fallout from the eruption was lacking. More recently, multiple studies have reported significant phytoplankton responses to volcanic ash supply; either following a natural deposition event (Hamme et al., 2010; Langmann et al., 2010a; Lin et al., 2011; Achterberg et al., 2013), or through controlled supply of ash to phytoplankton communities in shipboard bottle enrichment experiments (Achterberg et al., 2013; Browning et al., 2014a; Mélançon et al., 2014).

Recent reviews have summarized progress in constraining volcanic nutrient - and in particular Fe - supply to the ocean through consideration of ash formation, atmospheric processing, and solubility experiments (Duggen et al., 2010; Ayris and Delmelle, 2012; Langmann, 2014). The aims of the current manuscript are three-fold: After briefly introducing key marine biogeochemical provinces we extend prior reviews (Duggen et al., 2010; Ayris and Delmelle, 2012; Langmann, 2014) by synthesizing phytoplankton responses to ash supply; Secondly, in conjunction with new results from experiments assessing the optical properties of rhyolitic ash suspended in seawater, we present a remote sensing analysis of several previously unreported ash deposition events with fertilization potential; Thirdly, we calculate the uncertainty bounds of ash-fertilized carbon export for three deposition events. The biogeochemical implications of oceanic nutrient fertilization are of significant interest (Boyd et al., 2007, 2012; Sarmiento et al., 2010) and we conclude that well characterized volcanic ash deposition events could provide one such opportunistic platform for this research.

\section{POTENTIAL FOR VOLCANIC ASH FERTILIZATION: MARINE BIOGEOCHEMICAL PROVINCES AND DOCUMENTED RESPONSES \\ BIOGEOCHEMICAL PROVINCES}

Phytoplankton have an absolute Fe requirement resulting from the non-substitutable role of this metal as an electron transporter in photosynthesis and respiration (Raven et al., 1999; Morel et al., 2003). Deep waters upwelling in the high latitude North Pacific, Equatorial Pacific, and the Southern Ocean have lower dissolved Fe:nitrate ratios than those required by phytoplankton (e.g., Johnson et al., 1997; Parekh et al., 2005; Sunda, 2012; Twining and Baines, 2013). Consequently, with the onset of favorable conditions for accumulation of plankton biomass (e.g., Sverdrup, 1953; Platt et al., 1991; Behrenfeld, 2010; Taylor and Ferrari, 2011), dissolved Fe can decline to concentrations that 
restrict phytoplankton growth rates and standing stocks whilst nitrate remains available (Figure 1; Boyd et al., 2007; Moore et al., 2013). Strictly, both "high-nitrate low-chlorophyll" (HNLC) and "high-nitrate high-chlorophyll" (HNHC) conditions appear to occur in ocean regions where phytoplankton communities are experiencing Fe stress (e.g., Moore et al., 2007 found Fe-limited Southern Ocean phytoplankton at chlorophyll-a concentrations of $1.42 \mathrm{mg} \mathrm{m}^{-3}$; cf. global mean $\sim 0.3 \mathrm{mg} \mathrm{m}^{-3}$ ). Thus, our use of "HNLC" throughout this manuscript will simply refer generically to regimes where full utilization of available nitrate through phytoplankton growth is prevented for some reason (Cullen, 1991).

Leaching experiments conducted on volcanic ash have shown low macronutrient:micronutrient release ratios relative to the stoichiometric requirements of phytoplankton (Frogner et al., 2001; Stefánsdóttir and Gíslason, 2005; Duggen et al., 2007; Jones and Gislason, 2008; Lin et al., 2011; Olgun et al., 2013a,b). Whilst volcanic ash likely provides a limited supply of macronutrients to LNLC regions, these vast oligotrophic systems also represent a major niche for nitrogen fixing bacteria, which have additional $\mathrm{Fe}$ requirements due to the presence of this element within the required nitrogenase enzyme (Berman-Frank et al., 2001). Thus, Fe supply is anticipated to up regulate nitrogen fixation, thereby increasing the total fixed nitrogen inventory available to the phytoplankton community (Falkowski, 1997; Moore et al., 2009). However, in terms of phytoplankton biomass changes, responses to conventional dust deposition in these types of system have been highly variable (DiTullio and Laws, 1991; Young et al., 1991; Johnson et al., 2003; Westberry et al., 2005; Bonnet et al., 2008; Mackie et al., 2008; Moore et al., 2009; Schlosser et al., 2014), therefore phytoplankton responses to ash deposition should be anticipated to be similarly complex.

\section{SHIPBOARD BIOASSAY EXPERIMENTS}

A synthesis of phytoplankton responses to ash supply is provided in Table 1. Arguably the most convincing evidence that natural phytoplankton communities can access Fe supplied from volcanic ash has come from shipboard bioassay experiments that have detected changes in phytoplankton physiology (Achterberg et al., 2013; Browning et al., 2014a), biomass (Achterberg et al., 2013; Browning et al., 2014a; Mélançon et al., 2014), and community structure (Mélançon et al., 2014) that are consistent with relief of phytoplankton Fe limitation (Boyd et al., 2007). However, observed responses have not been consistent in either the magnitude of phytoplankton response to a given ash loading, or the relative response compared to parallel Fe-only treatment experiments. In the high latitude North Atlantic using fresh ash collected from the Eyjafjallajökull eruption $<3$ months previously, Achterberg et al. (2013) found a positive phytoplankton community-level response to ash supply, yet this was around half the magnitude of a $2 \mathrm{nmol} \mathrm{L}-1$ Fe-only treatment. This was despite deionized water (Milli-Q) leaching experiments with the Eyjafjallajökull ash indicating an upper bound Fe release of 4.6-16 nmol L ${ }^{-1}$. Conversely, Mélançon et al. (2014) observed changes in chlorophyll-a biomass in the North Pacific that generally matched Fe-only treatment-indicating full relief of Fe stress in both cases, and Browning et al. (2014a) who in the Southern Ocean reported responses to ash amendment that were equivalent, or in a number of cases significantly enhanced relative to the Fe-only treatment.

The inconsistency between experiments across the three oceanic regions tested, despite similar ash loadings, is strongly suggestive of the importance of the biogeochemical regime and physiological state of the extant phytoplankton population being tested in controlling observed responses - as might be anticipated in any nutrient treatment experiment. This includes variability in the solubility and/or accessibility of the volcanic Fe under the particular physical and chemical characteristics of the seawater in question and its interaction with a given ash sample. For example, the reduced response to ash observed by Achterberg et al. (2013) may reflect either that the ash-released Fe was not as accessible to the phytoplankton community as that from the Fe-only treatment (in this case in the form of $\mathrm{FeCl}_{3}$ ), or that the magnitude of Fe supply was simply lower, with experiments leaching significant Fe from the ash into Milli-Q water $(\mathrm{pH}<7)$ potentially overestimating that which actually occurred within the seawater experiments. In contrast, Browning et al. (2014a), found full relief of Fe stress by ash treatment in Southern Ocean waters with lowest dissolved Fe concentrations (Figures 2A,C), and suggested that the significant experimental responses to ash compared to that with Fe-only treatment in several instances may point to relief of trace metal (co)limitation (perhaps manganese (Mn)) (see Figure 2D).

As well as supplying essential trace elements, volcanic ash releases metals that can be toxic to phytoplankton at high concentrations (Morel et al., 2003; Hoffmann et al., 2012). However, the results from the shipboard bioassay experiments suggest that, at least at ash loadings used in experiments so far that were chosen to represent realistic ash supply to the open ocean, there is an absence of toxicity at the community level. This is demonstrated by the similar or greater stimulation of phytoplankton compared with Fe-only treatment in the cases of Mélançon et al. (2014) and Browning et al. (2014a), or in the case of Achterberg et al. (2013), a similar level of response between Fe-only and Fe plus ash treatment.

\section{LARGE SCALE BIOGEOCHEMICAL RESPONSES TO ASH DEPOSITION EVENTS}

Whilst the bottle-scale experiments have been essential tools for direct monitoring of the phytoplankton response to ash supply, observations during and subsequent to large-scale natural ash deposition events have provided further insight into the extent of the biogeochemical response of the system in question. Specifically, anomalously low post-bloom nitrate concentrations within the Icelandic Basin provided good evidence for enhanced phytoplankton growth subsequent to the 2010 Eyjafjallajökull ash deposition event (Achterberg et al., 2013) in a region where an annual phytoplankton bloom (e.g., Siegel et al., 2002) has been reported to be terminated by insufficient Fe (Ryan-Keogh et al., 2013). Enhanced satellite-detected chlorophyll-a concentrations were also observed, however Henson et al. (2013) concluded that anomalously reduced mixed layer depths provided more favorable irradiance conditions for phytoplankton in the same season as the 


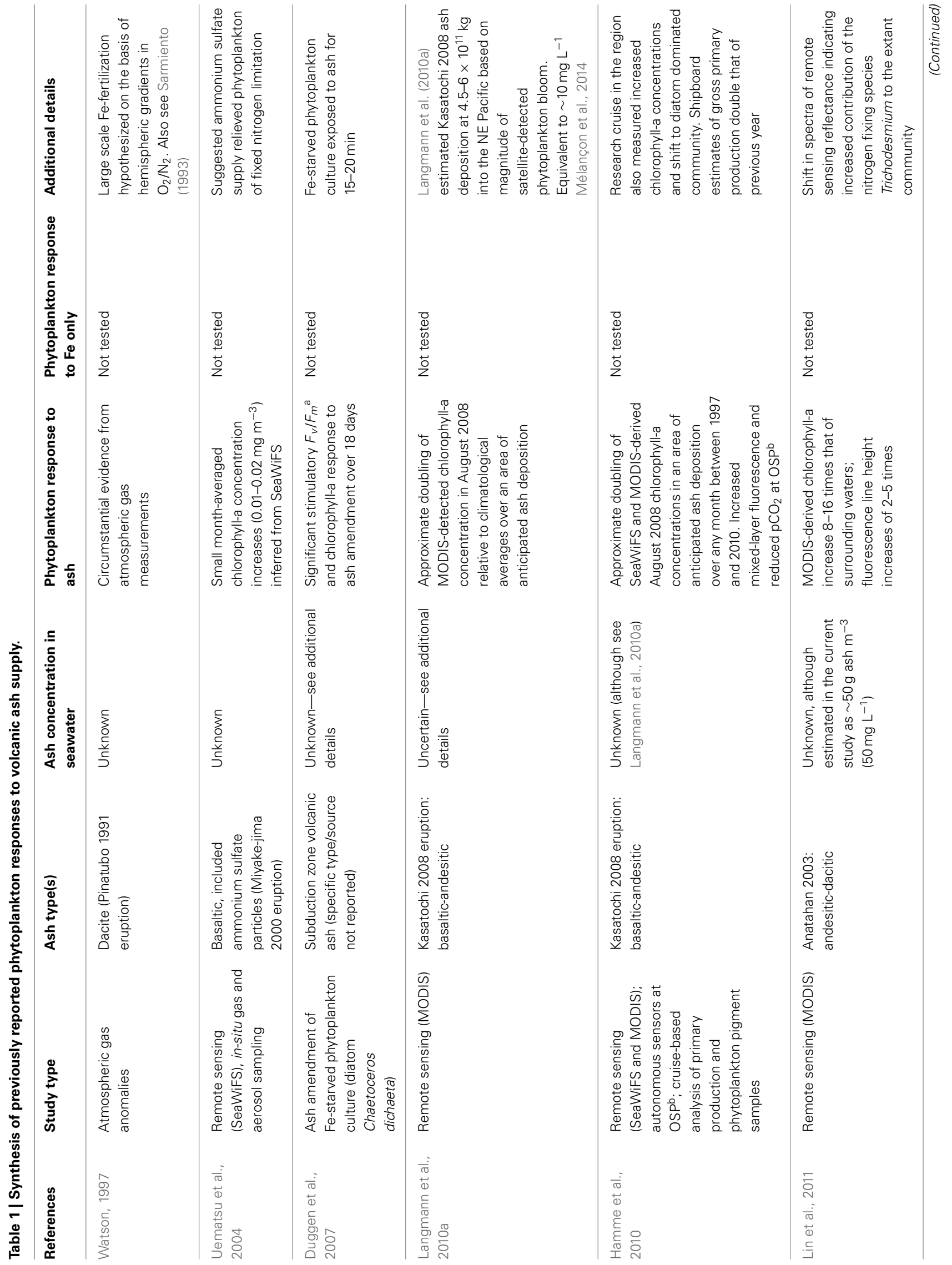




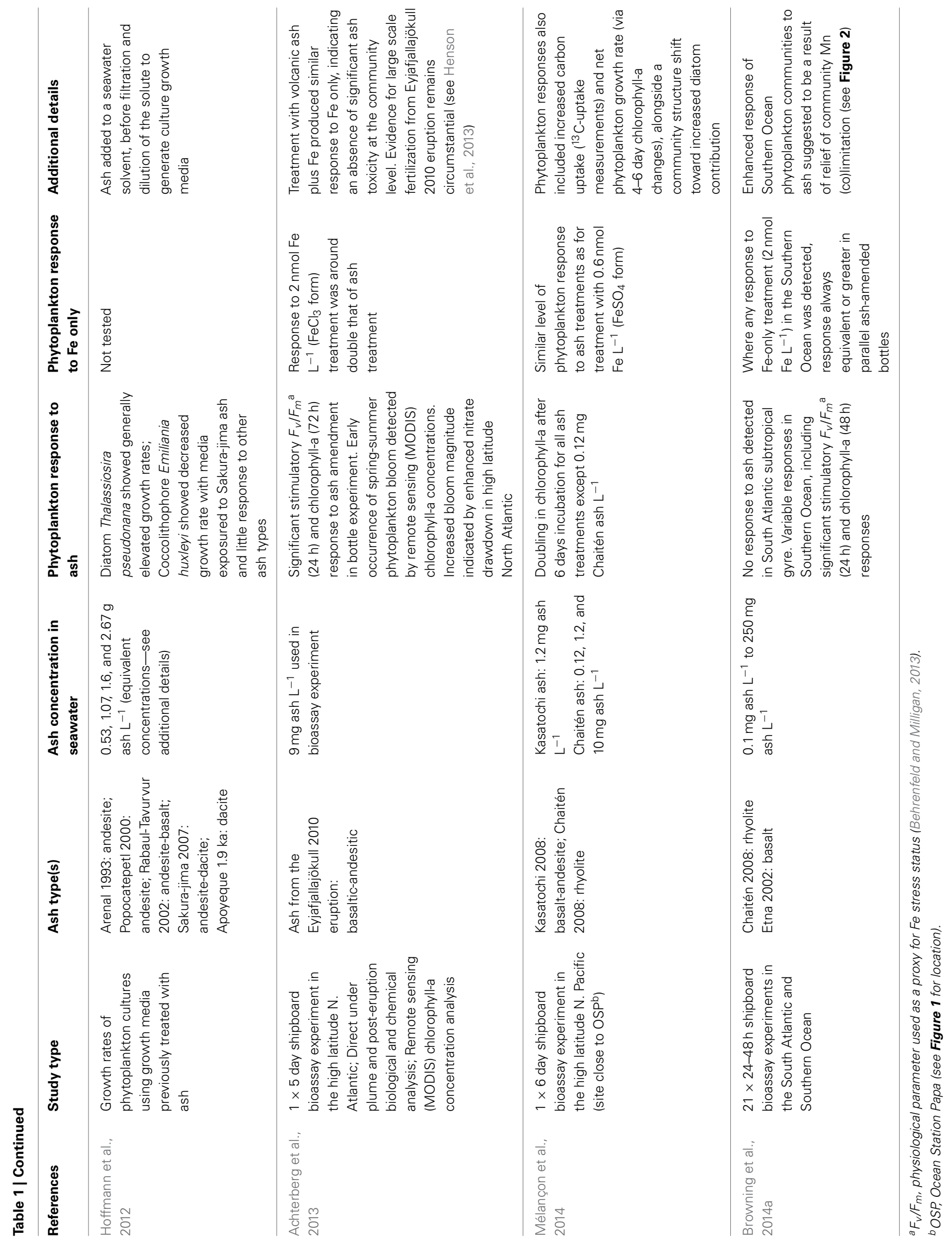



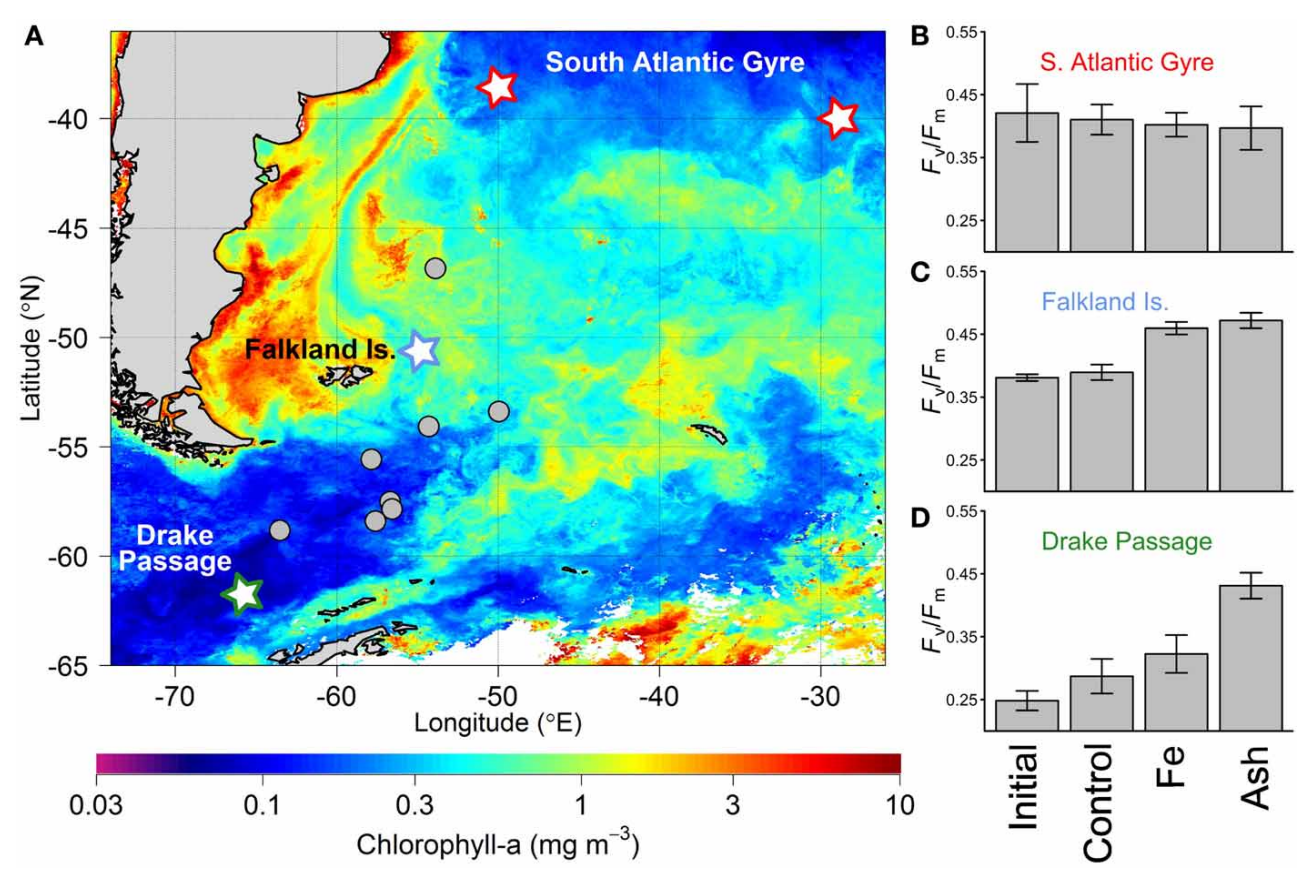

FIGURE 2 | Bottle-scale 24-h duration ash addition experiments performed by Browning et al. (2014a). (A) Satellite-derived chlorophyll-a concentrations averaged over the time period of experiments

(January-March 2012). Experiment locations are plotted, with those highlighted in (B-D) identified with a related color star. (B-D)

Phytoplankton community-level $F_{V} / F_{m}$ response to separate $\mathrm{Fe}$ and ash addition experiments in three distinct biogeochemical regimes. Bars and error bars indicate the mean and standard deviation of responses respectively. "Initial" indicates initial phytoplankton $F_{v} / F_{m}$ (results for both subtropical gyre experiments highlighted in $(\mathbf{A})$ were averaged, thus $n=6$, whilst for Falkland Islands and Drake Passage, $n=3)$; "Control" indicates bottles incubated for $24 \mathrm{~h}$ but with no treatment (subtropical gyre, $n=6$; Falkland Islands and Drake Passage, $n=3)$; "Fe" indicates addition of $2 \mathrm{nmol} \mathrm{L} \mathrm{L}^{-1} \mathrm{Fe}$ (in the form of $\mathrm{FeCl}_{3}$ ) (subtropical gyre, $n=6$; Falkland Islands and Drake Passage, $n=3$ ). "Ash" indicates the average response to both rhyolite and basaltic ash addition as responses to the two ash types were similar ( $n=6$ for each of the three regions). Initial nutrient concentrations for the three sites were (subtropical gyre, Falkland Is., Drake Passage): nitrate ( $\left.\mu \mathrm{mol} \mathrm{L}{ }^{-1}\right)$ : 0.04, 15.6, 22.7; Fe $\left(\mathrm{nmol} \mathrm{L}^{-1}\right)$ : 0.31, $0.20,0.25$; and $\mathrm{Mn}\left(\mathrm{nmol} \mathrm{L}^{-1}\right)$ : $0.31,0.12,0.05$. ash deposition event, complicating attribution of the enhanced phytoplankton bloom in this year.

More convincing evidence of large-scale ash fertilization has come from multiple observations of the Kasatochi 2008 deposition event in the high latitude North Pacific (Hamme et al., 2010; Langmann et al., 2010a). Satellite-derived chlorophyll-a concentrations averaged for August 2008 over an area downwind (east) of the eruption and within a region shown to be Fe-stressed at this time of year (Tsuda et al., 2003; Boyd et al., 2004) were double that of any monthly average since 1997 (Hamme et al., 2010; Figure 3A). Critically, ground-based measurements strongly supported the occurrence of enhanced phytoplankton growth after the ash deposition event. Ash was entrained in a storm system, and deposited over a wide areal extent, including the Ocean Station Papa (OSP) site where a sea glider detected enhanced chlorophyll-a fluorescence and a $\mathrm{pCO}_{2}$ $\left(\mathrm{CO}_{2}\right.$ partial pressure) instrument at Station $\mathrm{P}$ monitored clear reductions suggesting enhanced phytoplankton growth (Hamme et al., 2010). These measurements were supported by cruise-based observations of enhanced chlorophyll-a and a phytoplankton community structure shift toward an increased contribution of diatoms. Later studies have suggested that this diatom bloom fueled higher trophic levels in the Gulf of Alaska: specifically zooplankton in 2008 (Hamme et al., 2010) and sockeye salmon in 2010 (Parsons and Whitney, 2012; Olgun et al., 2013b).

There have been few investigations of phytoplankton responses to ash supply in LNLC regions, both in terms of shipboard bioassay experiments and larger scale biogeochemical responses subsequent to natural events. Browning et al. (2014a) performed ash amendment experiments in the South Atlantic subtropical gyre, yet observed no response in the 24-h duration experiments. It remains possible that some level of response may have been observed in longer duration experiments, where the stimulation of initially rare nitrogen fixing cyanobacteria increases the fixed nitrogen inventory for the extant phytoplankton community. Indeed, Lin et al. (2011) reported apparent chlorophyll-a concentrations to increase to 8-16 times that of surrounding LNLC oligotrophic waters subsequent to the 2003 Anatahan eruption, alongside a spectral shift in satellite-retrieved radiances consistent with a change in community composition toward an increased contribution of the nitrogen fixing species Trichodesmium.

\section{OBSERVING BIOGEOCHEMICAL RESPONSES TO ASH DEPOSITION: CHLOROPHYLL-A REMOTE SENSING AND CONSTRAINING UNCERTAINTY IN CARBON EXPORT}

Remote sensing provides both invaluable quasi-synoptic coverage of ocean color (and thus a means to estimate chlorophyll-a 


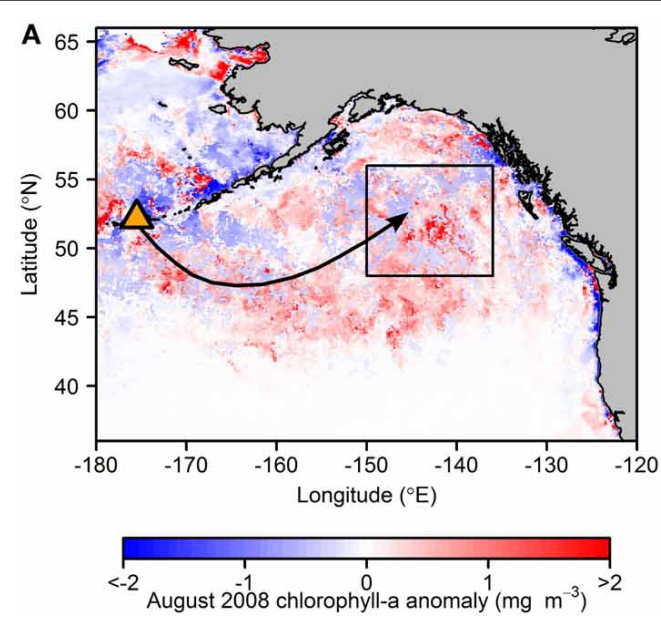

FIGURE 3 | Enhanced chlorophyll-a concentrations subsequent to the Kasatochi 2008 eruption (after Hamme et al., 2010; Langmann et al., 2010a,b). (A) August 2008 chlorophyll-a anomaly relative to the 2002-2013 August average. The Kasatochi volcano has been identified with an orange triangle; the general trajectory of the

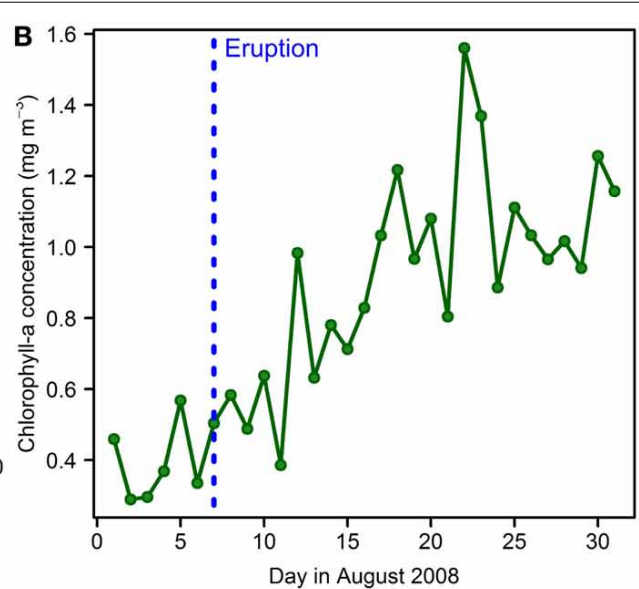

ash cloud is indicated by an arrow. (B) Daily-resolved chlorophyll-a concentrations for August 2008 averaged over the box area drawn in (A). The eruption date is shown by the blue dashed line, after which chlorophyll-a concentrations begin increasing (following a time lag of several days). concentrations) and atmospheric aerosol loading; however, as acknowledged in studies focusing on conventional dust-fueled fertilization events (Boyd et al., 2010), linking the two causatively without field observations is potentially complicated by a range of factors. Spatial coverage of satellite-retrieved ocean color for a given day or composited over a weekly timescale can be far from complete, whilst compositing over longer time periods could hide spatial and temporal patterns between a given ash deposition event and phytoplankton response. Furthermore, phytoplankton responses in the ocean will rarely be as simple as observed in a bottle experiment (Cullen et al., 1992), with a multitude of complex and interacting physical (e.g., Lewis et al., 1984; Platt et al., 1991; Abraham, 1998; Abraham et al., 2000) and ecological (e.g., Banse, 1992; Landry et al., 2000; Behrenfeld, 2010; Behrenfeld et al., 2013) factors, in addition to nutrient availability, regulating the standing stock of phytoplankton at any given point and time. These factors are not easily recovered by remote sensing, typically requiring a suite of detailed measurements at sea to resolve (e.g., Boyd et al., 2007; Landry et al., 2009). Additionally, chlorophyll-a concentrations are not a direct measure of phytoplankton biomass (e.g., Strickland, 1960; Cullen, 1982), as pigment:carbon ratios are strongly dependent on growth conditions (e.g., Geider, 1987). Finally, loading of surface waters with volcanic ash may alter optical properties of seawater such that chlorophyll-a concentrations estimated using conventional ocean-color sensors and algorithms would be ambiguous.

Despite the array of aforementioned difficulties, the often remote and sporadic nature of ash deposition events mean that detection via satellite is typically the only method of observation available; justifying the current effort to constrain potential for monitoring ash-mediated fertilization in this manner. Moreover the point-source and often transient nature of volcanic eruptions alongside their coincident diagnostic gas emission should make ash deposition events more easily traceable via remote sensing than regular desert dust. In the following section we conduct a study to (i) evaluate the potential impact of suspended ash on chlorophyll-a concentrations estimated by conventional Case 1 ocean-color algorithms, and (ii) perform a retrospective analysis of events depositing ash into ocean waters spanning a range of biogeochemical settings. We finish by evaluating the potential role of ash fertilization on carbon export using current estimates of nutrient release from volcanic ash and carbon export efficiencies.

\section{MATERIALS AND METHODS \\ Determining the inherent optical properties of rhyolitic ash suspended in seawater}

Inherent optical properties relevant for satellite ocean color remote sensing were assessed for Chaitén ash samples suspended in filtered seawater $\left(0.2 / 0.2 \mu \mathrm{m}\right.$ Pall Acropak1000 ${ }^{\circledR}$ Capsule) using a flow through system in-line with optical sensors (Dall'Olmo et al., 2009). The Chaitén ash used was sample 05-15b of Watt et al. (2009) from the May 2008 eruption, as used in the bottle-scale fertilization experiments of Browning et al. (2014a). The ash sample had a modal grain size of $62.5 \mu \mathrm{m}$ and was almost exclusively a rhyolitic glass (bulk density of individual particles of rhyolite glass $\sim 2400 \mathrm{~kg} \mathrm{~m}^{3}$; some particles in the $>100 \mu \mathrm{m}$ fraction are vesicular so bulk particle densities of these individual particles will be lower) (Watt et al., 2009). Details of the 2008 source eruption, ash collection, and bulk chemical analyses are described in Watt et al. (2009). Optical backscattering coefficients $\left(b_{b}(\lambda)\right)$ were measured at three wavelengths $(470,532$, and $700 \mathrm{~nm})$ using an ECO-BB3 backscattering meter (WET Labs). Absorption coefficients $(a(\lambda))$ were measured at nine wavelengths $(412,440,488,510,532,555,650$, 676 , and $715 \mathrm{~nm}$ ) over a $25 \mathrm{~cm}$ path length using an ac- 9 spectral absorption-attenuation meter (WET Labs) (Dall'Olmo et al., 2009). Each experimental session started with cleaning the system 
(4.06 L volume) with Decon 90 and a weak solution of bleach that was rinsed and drained before refilling with filtered seawater. A known amount of ash mass was then added directly to the system at progressively increasing concentrations (see Table 1 for ash concentrations). Water with the new sample addition was circulated through the system using a peristaltic pump (Watson Marlow) at $4 \mathrm{~L} \mathrm{~min}{ }^{-1}$ for at least $3 \mathrm{~min}$ or until readings were stable. Following this the pump was switched off and real-time observations of backscattering and absorption were recorded for 3 min (fluctuations within this time were less than $5 \%$ of the signal magnitude).

As has been found previously for measurement of pure quartz particle suspensions (e.g., Babin and Stramski, 2004; Stramski et al., 2007) absorption coefficients for the Chaitén ash were below the detectable level of the instrument across the entire spectrum (limit of detection for the ac- 9 reported as $3 \times$ standard deviation of blanks is $\sim 0.009 \mathrm{~m}^{-1}$; Twardowski et al., 1999). For this reason we assumed a spectrally-insensitive value of $0.0001 \mathrm{~m}^{2} \mathrm{~g}^{-1}$ that is consistent with the lowest values reported in the modeling study of Wozniak and Stramski (2004). Particulate backscattering coefficients at a given concentration $\left(b_{b p \text {, raw }}\right)$ were derived as recommended by the manufacturer using modifications for chamber measurements (Dall'Olmo et al., 2009):

$$
b_{b p, \text { raw }}=2 \pi \chi_{p}\left(\beta-\beta_{S W}\right)-b_{b, \text { wall }},
$$

where $\chi_{p}$ is conversion factor (1.076, Sullivan et al., 2013), $\beta$ is the volume scattering function at the measurement angle of the backscattering meter $\left(124^{\circ}\right)$, and $b_{b}$, wall is the backscattering coefficient associated with the flow-through tube. The pure water volume scattering function $\left(\beta_{S W}\right)$ from Zhang et al. (2009) $\left(T=21.3{ }^{\circ} \mathrm{C}, S=35.1 \mathrm{psu}\right)$ was subtracted from $\beta$. Values of $b_{b p \text {, raw }}$ were then converted to an ash-only backscattering $\left(b_{b p, a s h}\right)$ by subtracting the $b_{b p \text {,raw }}$ of the filtered seawater case from the ash-loaded case in order to remove any potential background contamination in the system. Mass-specific ash backscattering $\left(b_{b p, a s h}^{*}\right)$ were calculated by dividing $b_{b p, a s h}$ by the ash concentration.

We followed the approach of Wozniak and Stramski (2004) to estimate the relative contribution of suspended ash to chlorophyll concentrations retrieved by ocean color sensors and Case 1 algorithms. Firstly the remote sensing reflectance values $\left(R_{r s}(\lambda)\right)$, from which satellite-based chlorophyll-a concentrations are derived, were assumed to vary as the ratio of the total seawater backscattering to the sum of the total seawater backscattering and absorption coefficients:

$$
R_{r s}(\lambda) \propto \frac{b_{b}(\lambda)}{b_{b}(\lambda)+a(\lambda)},
$$

where $b_{b}$ is total backscattering coefficient of seawater and $a$ is total absorption coefficient of seawater. The total backscattering and absorption of seawater includes the individual components of phytoplankton, ash and the seawater itself:

$$
\begin{aligned}
a(\lambda) & =a_{w}(\lambda)+a_{a s h}^{*}(\lambda) C+a_{p}(\lambda), \\
b_{b}(\lambda) & =b_{b, w}(\lambda)+b_{b p, a s h}^{*}(\lambda) C+b_{b, p}(\lambda),
\end{aligned}
$$

where $a_{w}$ is absorption of pure seawater, $a_{a s h}^{*}$ is the mass-specific absorption of ash particles, $C$ is ash particle concentration, and $a_{p}$ is absorption of phytoplankton (and equivalent for backscattering). Absorption and backscattering for pure seawater and phytoplankton were parameterized as for Wozniak and Stramski (2004) (and references therein). Backscattering coefficients for the Chaitén ash at the wavelengths used by ocean color sensors were estimated from the values in Table 2 and the following power law (Snyder et al., 2008):

$$
b_{b p, a s h}^{*}(\lambda)=b_{b p, a s h}^{*}(532)\left(\frac{\lambda}{532}\right)^{-\eta}
$$

Where $\eta$ was determined from an ordinary least squares regression on the log-transformed values of $b_{b, a s h}^{*}$ and $\lambda$. Chlorophyll-a concentrations estimated from ocean color typically use Case 1 algorithms that employ the ratio of retrieved remote sensing reflectance in the blue and green regions of the spectrum $\left(R_{r}\right)$ alongside an empirically derived relationship with chlorophyll-a:

$$
\begin{gathered}
R_{r}=\log \left(\frac{R_{r s}(\text { blue })}{R_{r s}(\text { green })}\right) \\
\text { Chlorophyll- } a=10^{\left(a_{0}+a_{1} R_{r}+a_{2} R_{r}^{2}+a_{3} R_{r}^{3}+a_{4} R^{4}\right)}
\end{gathered}
$$

Where blue and green represent chosen wavelengths that differ for the various ocean color sensors and associated algorithms. We used the OC $3 \mathrm{M}-547$ algorithm that is used by the NASA ocean color processing group to generate the MODIS chlorophyll-a images in this paper (see: http://oceancolor.gsfc. nasa.gov/REPROCESSING/R2009/ocv6/). For this algorithm $R_{r s}$ (blue) is the larger of either $R_{r s}(443)$ or $R_{r s}(489)$ and $R_{r s}$ (green) is $R_{r s}(547)$ and the empirically derived parameters are: $a_{0}=0.02424 ; a_{1}=-2.7423 ; a_{2}=1.8017 ; a_{3}=-0.0015$; $a_{4}=-1.2280$.

\section{Table 2 | Inherent optical properties of Chaitén ash ${ }^{\mathrm{a}}$.}

\begin{tabular}{lccc}
\hline Ash concentration $\left(\mathbf{g ~ m}^{-\mathbf{3}}\right)$ & \multicolumn{3}{c}{$\boldsymbol{b}^{*}{ }_{\text {, }, \text { ash }}(\lambda)\left[\mathbf{m}^{\mathbf{2}} \mathbf{g}^{\mathbf{- 1}}\right]$} \\
\cline { 2 - 4 } & $\mathbf{4 7 0}$ & $\mathbf{5 3 2}$ & $\mathbf{7 0 0}$ \\
\hline 10.8 & 0.00019 & 0.00014 & 0.00007 \\
16.6 & 0.00017 & 0.00012 & 0.00006 \\
26.7 & 0.00020 & 0.00013 & 0.00008 \\
35.1 & 0.00014 & 0.00010 & 0.00007 \\
50.4 & 0.00016 & 0.00011 & 0.00007 \\
\hline Median $b^{*}{ }_{b, a s h}(\lambda)\left[\mathrm{m}^{2} \mathrm{~g}^{-1}\right]$ & 0.00017 & 0.00012 & 0.00007 \\
\hline $\mathrm{SD} b^{*}{ }_{b, a s h}(\lambda)\left[\mathrm{m}^{2} \mathrm{~g}^{-1}\right]$ & $2.23 \mathrm{E}-05$ & $1.65 \mathrm{E}-05$ & $7.33 \mathrm{E}-06$ \\
\hline
\end{tabular}

${ }^{a} b_{b, m}^{*}$ is the mass specific backscattering of suspended ash for the 5 loading experiments; $S D=$ standard deviation. The median percentage uncertainties of $b_{b, \text { wall }}$ on $b_{b p \text {, raw }}$ (see Section: "Determining the Inherent Optical Properties of Rhyolitic Ash Suspended in Seawater") for the suite of ash concentrations were $9 \%, 8 \%$ and $14 \%$ respectively for the three backscattering channels 1470,532 , and $700 \mathrm{~nm})$. 


\section{Determining the impact of suspended ash on light availability for phytoplankton}

Using the inherent optical properties described previously (Section: "Determining the Inherent Optical Properties of Rhyolitic Ash Suspended in Seawater"), a simple calculation was performed to evaluate the impact of suspended Chaitén ash on light availability for phytoplankton. The vertical attenuation coefficient for downward irradiance at the mid-point of the photic zone $\left(K_{d}\left(z_{m, \lambda}\right)\right)$ was calculated using the equation presented by Kirk (1981):

$$
K_{d}\left(z_{m}, \lambda\right)=\left[a(\lambda)^{2}+0.256 a(\lambda) b_{b}(\lambda)\right]^{0.5}
$$

where $a(\lambda)$ and $b_{b}(\lambda)$ are total seawater absorption and backscattering at a given wavelength, $\lambda$ (see Equations 3-4), and $z_{m}$ is the mid-point of the euphotic zone. $K_{d}\left(z_{m}, \lambda\right)$ at $\lambda=443 \mathrm{~nm}$ calculated for waters containing suspended ash was divided by the case with no ash to give the relative influence of ash on light attenuation at this wavelength. Making the assumption of a constant $K_{d}$ throughout the photic zone, this quotient is equivalent to the factor that the euphotic depth (i.e., depth at which light is $1 \%$ of its surface value) would be reduced by.

\section{Remote sensing data}

All chlorophyll-a products used in this study are 4-km resolution L3 MODIS composites either at 1-day, 8-day or monthly averaged formats available from NASA (see: http://oceancolor. gsfc.nasa.gov/). These products have been generated using the OC3M-547 algorithm developed for open ocean Case 1 waters. Case 1 waters are those in which phytoplankton and co-varying biological material are predominantly responsible for controlling the inherent optical properties of the water (Gordon and Morel, 1983). Alongside the presence of any other non-algal particles, suspended volcanic ash is not accounted for in the atmospheric correction for water-leaving radiances used in this algorithm, with the magnitude and sign of any resultant bias unknown. Using new optical measurements we present the first quantitative analysis of the potential impact of suspended volcanic ash on retrieved chlorophyll-a to assess for bias in each of the presented case studies (see Section: "Determining the Inherent Optical Properties of Rhyolitic Ash Suspended in Seawater").

Various approaches have been employed for observing the spatial extent and loading of ash plumes; in this study we used UV aerosol index products from: (i) the Total Ozone Mapping Spectrometer (TOMS) on the Nimbus-7 satellite for data from 1978 to 1993 (e.g., Seftor et al., 1997) and, (ii) the Ozone Monitoring Instrument (OMI) on the EOS-Aura satellite for data from 2004-present (e.g., Torres et al., 2007). Products from both missions are available from NASA (http://ozoneaq.gsfc.nasa. gov/).

To aid with interpretation of chlorophyll-a changes as a function of ash loading, satellite products for other key physical variables potentially regulating phytoplankton dynamics were downloaded: MODIS sea surface temperature at the same temporal and spatial resolutions as chlorophyll-a; fields of multisensor blended wind stress from the NOAA National Climatic Data Center (http://ncdc.noaa.gov/); and images of sea surface height from the Colorado Center for Astrodynamics Research (http://eddy.colorado.edu/ccar/ssh/hist_global_grid_viewer).

Ash deposition events investigated (Table 3) were targeted as those sourced from eruptions with larger explosivity and eruption volumes (Volcanic Explosivity Index, VEI>3) and with a greater chance of deposition over the ocean. Chlorophyll-a responses were evaluated as post-ash deposition concentration changes around a pre-eruption baseline over a spatial region of anticipated ash deposition inferred from the aerosol products (see Figure 4 caption for further details).

\section{Calculations of potential bounds for ash-fertilized carbon export}

Assuming known masses of ash deposition and, guided by published estimates, prescribing continuous vectors of Fe release efficiency (Fe release per unit mass of ash) and carbon export efficiency (carbon sequestration per unit mass of Fe addition), matrices of potential carbon export were calculated for 3 events varying by two orders of magnitude by mass of oceanic ash deposition.

A crude estimate of ash deposition was calculated for the past $16.5 \mathrm{kyr}$ for the volcanoes of present-day southern Chile and Patagonia (Llaima to Hudson-see Figure 1; Watt et al., 2013; Fontijn et al., 2014). In this arc segment, 87 explosive eruptions from 24 volcanoes are known to have had eruptions with a VEI of at least 4 , with a minimum eruptive yield of $132 \mathrm{~km}^{3}$ of tephra in $16.5 \mathrm{kyr}$ (Watt et al., 2013). Each of these eruptions would have delivered substantial volumes of ash to the Southern Ocean, both during eruptions, and through later wind-borne remobilization. Studies of the Hudson 1991 and Chaitén 2008 eruptions have suggested that at least $30-40 \%$ of the erupted ash volume in each case was deposited as primary ash fallout to the South Atlantic-Southern Ocean (Scasso et al., 1994; Watt et al., 2009). This proportion is conservative-and will be higher for larger eruptions as the dispersal area increases. Assuming 35\%, and a (conservative) ash bulk density of 1 ton $\mathrm{m}^{-3}$ produces an ash mass flux of $\sim 50 \mathrm{Pg}$. Whilst the bulk Fe content of rhyolitic ash can reach $>4 \%$ (e.g., Watt et al., 2009), recent experiments (e.g., Duggen et al., 2007; Jones and Gislason, 2008; Olgun et al., 2011; Achterberg et al., 2013; Browning et al., 2014a; Mélançon et al., 2014) suggest that the majority of this Fe does not become part of the dissolved pool on the timescale the ash sinks through the water column ( $<1-2$ days; Duggen et al., 2007). Therefore, we refined the assumption made in the earlier calculation of Watson (1997), who estimated 1\% by weight of deposited Pinatubo ash to be bioavailable Fe, by assuming an Fe release range of $1 \times 10^{-6}$ to $1 \times 10^{-5} \mathrm{~g} \mathrm{Fe}(\mathrm{g} \text { ash) })^{-1}$ (equivalent to a solubility of $0.025-$ $0.0025 \%$ for a $4 \mathrm{wt} \%$ Fe content of ash; after Gaiero et al., 2003; Watt et al., 2009). The lower end of this range reflects the results of Browning et al. $(2014 \mathrm{a})\left(\sim 1 \times 10^{-6} \mathrm{~g} \mathrm{Fe}(\mathrm{g} \text { ash })^{-1}\right)$ and Mélançon et al. $(2014)\left(\sim 1.7 \times 10^{-6}\right.$ g Fe: $(\mathrm{g} \text { ash })^{-1}$, inferred from the reported $\sim 0.1-0.5 \mathrm{nmol} \mathrm{L}{ }^{-1}$ dissolved Fe increase in seawater subsequent to addition of $10 \mathrm{mg}$ ash $\mathrm{L}^{-1}$ ), whilst the

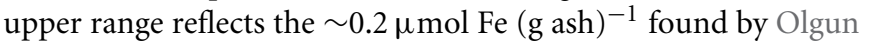
et al. (2011). With these assumptions Patagonian total $16.5 \mathrm{ka}$ to present-day volcanic Fe supply was calculated as $50-500 \mathrm{Gg}$ Fe.

Calculated ranges of Fe release were used alongside a potential range of carbon export efficiency. Considerable uncertainty also 
Table 3 | Summary of remote sensing case studies discussed in order of occurrence (1999-2014) ${ }^{\mathrm{a}}$.

\begin{tabular}{|c|c|c|c|c|c|c|c|c|}
\hline Volcano name & Region & Regime & $\begin{array}{l}\text { Eruption } \\
\text { start date }\end{array}$ & $\begin{array}{l}\text { Max. } \\
\text { VEI }\end{array}$ & Ash type & $\begin{array}{l}\text { Sat. chl-a } \\
\text { increase } \\
\text { detected? }\end{array}$ & Comment & References \\
\hline Miyake-jima & W. St. Pacific & LNLC & Jun 27th 2000 & 3 & Basaltic & Yes* & $\begin{array}{l}\text { Fertilization through supply of } \\
\text { ammonium sulfate? }\end{array}$ & $\begin{array}{l}\text { Uematsu et al., } \\
2004\end{array}$ \\
\hline Ruang & $\begin{array}{l}\text { W. Pacific } \\
\text { (equatorial) }\end{array}$ & LNLC & Sep 25th 2002 & 4 & $\begin{array}{l}\text { Basaltic- } \\
\text { andesitic }\end{array}$ & No & $\begin{array}{l}\text { Onshore winds_limited ash } \\
\text { dispersion over ocean }\end{array}$ & This study \\
\hline Reventador & $\begin{array}{l}\text { E. Pacific } \\
\text { (equatorial) }\end{array}$ & HNLC & Nov 3rd 2002 & 4 & Andesitic & No & Poor satellite coverage & This study \\
\hline Anatahan & $\begin{array}{l}\text { W. Pacific } \\
\text { (subtropical) }\end{array}$ & LNLC & May 10th 2003 & 3 & $\begin{array}{l}\text { Andesitic- } \\
\text { dacitic }\end{array}$ & Yes* $^{*}$ & $\begin{array}{l}\text { Chlorophyll-a increase and } \\
\text { remote sensing of } \\
\text { Trichodesmium }\end{array}$ & Lin et al., 2011 \\
\hline Sierra Negra & $\begin{array}{l}\text { E. Pacific } \\
\text { (equatorial) }\end{array}$ & HNLC & Oct 22nd 2005 & 3 & Basaltic & No & & This study \\
\hline La Cumbre & $\begin{array}{l}\text { E. Pacific } \\
\text { (equatorial) }\end{array}$ & HNLC & May 13th 2005 & 2 & Basaltic & No & & This study \\
\hline Rabaul & $\begin{array}{l}\text { W. Pacific } \\
\text { (equatorial) }\end{array}$ & LNLC & Aug 11th 2006 & 4 & $\begin{array}{l}\text { Andesitic- } \\
\text { dacitic }\end{array}$ & No & $\begin{array}{l}\text { Onshore winds_limited ash } \\
\text { dispersion over ocean }\end{array}$ & This study \\
\hline Llaima & S. Atlantic & HNLC & Jan 1st 2008 & 3 & $\begin{array}{l}\text { Basaltic- } \\
\text { andesitic }\end{array}$ & No & Limited ash deposition? & This study \\
\hline Chaitén & S. Atlantic & HNLC & May 2nd 2008 & 4 & Rhyolitic & Yes & $\begin{array}{l}\text { Anomalously high } \\
\text { chlorophyll-a in } \\
\text { Malvinas-Brazil confluence }\end{array}$ & This study \\
\hline Kasatochi & N. Pacific & HNLC & Aug 7th 2008 & 4 & $\begin{array}{l}\text { Basaltic- } \\
\text { andesitic }\end{array}$ & Yes & $\begin{array}{l}\text { Supporting ancillary } \\
\text { measurements from } \\
\text { OSP/routine OSP cruises }\end{array}$ & $\begin{array}{l}\text { Hamme et al., } \\
\text { 2010; Langmann } \\
\text { et al., 2010a }\end{array}$ \\
\hline Eyjafjallajökull & N. Atlantic & HNLC & Mar 20th 2010 & 4 & $\begin{array}{l}\text { Basaltic- } \\
\text { andesitic }\end{array}$ & Yes & $\begin{array}{l}\text { Chlorophyll-a anomaly but } \\
\text { uncertain if ash causative }\end{array}$ & $\begin{array}{l}\text { Achterberg et al., } \\
\text { 2013; Henson } \\
\text { et al., } 2013\end{array}$ \\
\hline Merapi & $\begin{array}{l}\text { E. Indian } \\
\text { (equatorial) }\end{array}$ & LNLC & Oct 26th 2010 & 4 & Andesitic & No & Poor satellite coverage & This study \\
\hline $\begin{array}{l}\text { Puyehue-Cordón } \\
\text { Caulle }\end{array}$ & $\begin{array}{l}\text { S. Atlantic/S. } \\
\text { Ocean }\end{array}$ & HNLC & Jun 4th 2011 & 5 & Rhyolitic & No & $\begin{array}{l}\text { Poor satellite coverage; } \\
\text { austral winter-phytoplankton } \\
\text { light-limited? }\end{array}$ & This study \\
\hline Kelud & $\begin{array}{l}\text { E. Indian } \\
\text { (equatorial) }\end{array}$ & LNLC & Feb 26th 2014 & 4 & $\begin{array}{l}\text { Basaltic- } \\
\text { andesitic }\end{array}$ & No & Poor satellite coverage & This study \\
\hline
\end{tabular}

${ }^{a}$ See Figure 1 for geographic locations of volcanoes. VEI, Volcanic explosivity index; HNLC, high-nitrate, low-chlorophyll; LNLC, low-nitrate, low chlorophyll; OSP, Ocean Station Papa. "Poor satellite coverage" indicates that a high proportion of pixels in images of interest were masked, for example due to cloud cover, high sun glint, low winter irradiance etc. Satellite chlorophyll-a changes highlighted with a star are events with seaward ash deposition into waters with ocean color coverage that have low initial chlorophyll-a concentrations $\left(<0.1 \mathrm{mg} \mathrm{m}^{-3}\right)$; optical experiments on rhyolitic ash conducted in this study suggest significant resultant chlorophyll-a bias in such cases (see Figure 4). Eruption start dates, VEl's, and ash types are from http://www.volcano.si.edu/.

exists in this latter parameter (e.g., De Baar et al., 2005; Sarmiento et al., 2010; Boyd et al., 2012), yet what has become evident from recent deliberate Fe fertilization experiments and observations of natural Fe enrichments is that the amount of Fe addition required for a given mass of carbon export appears to be far greater (i.e., less carbon export per added Fe) than projected using typical stoichiometric requirements measured in phytoplankton [also assumed in the earlier calculation of Watson (1997)]. We use a range in carbon export efficiency of $1000-30,000 \mathrm{~g} \mathrm{C}(\mathrm{g} \mathrm{Fe})^{-1}$ that encompasses the results of several $\mathrm{Fe}$ natural and anthropogenic 


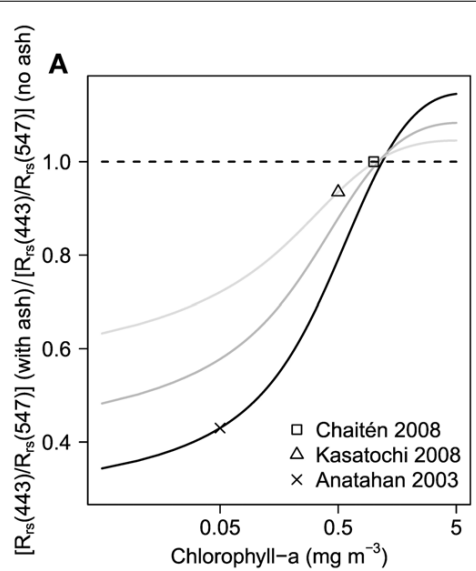

FIGURE 4 | Relative influence of suspended Chaitén ash on $(A)$ the satellite-retrieved blue:green $R_{r s}$ ratio, $(B)$ resultant OC3-derived chlorophyll-a concentrations (using $\boldsymbol{R}_{\boldsymbol{r}}=\boldsymbol{R}_{r s}(\mathbf{4 4 3}) / \boldsymbol{R}_{r s}(547)$ ), and (C) $\boldsymbol{K}_{\boldsymbol{d}}\left(\mathbf{z}_{\boldsymbol{m}}, \lambda\right)$. Ash-biased values are normalized to the no-ash case for three ash loadings at a range of seawater chlorophyll-a concentrations. The influences of the expected ash loading for three eruptions that have been investigated for phytoplankton response in this study are highlighted (note that apart from Chaitén 2008, the applicability of these optical properties to the other ash types are uncertain). "Actual" seawater chlorophyll-a has been estimated from the pre-eruption satellite-retrieved concentrations. The estimated ash loading has a variable sensitivity to the relative level of bias depending on the
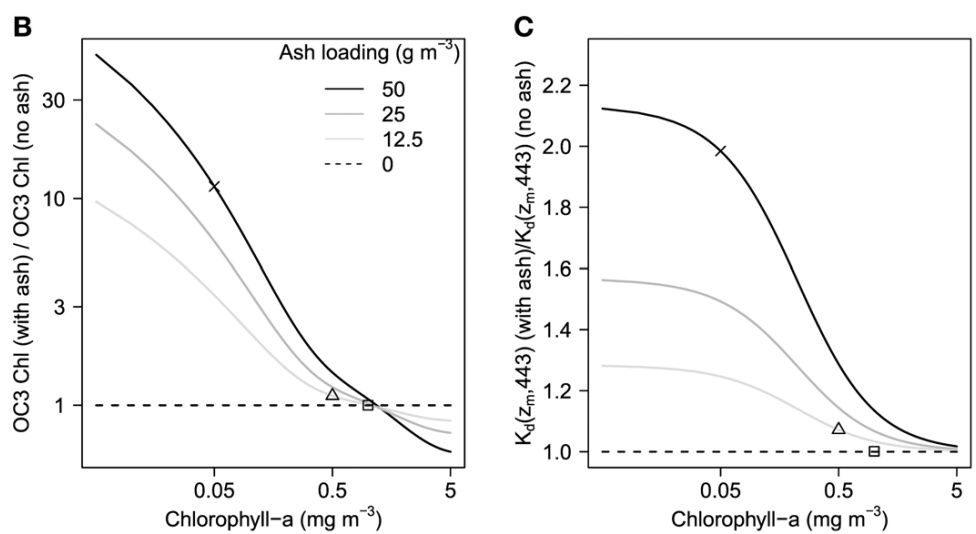

seawater chlorophyll-a concentration (note the logarithmic scale on the vertical axis in B). For each of the highlighted case studies ash loading has been estimated as follows; Kasatochi 2008: $10 \mathrm{~g} \mathrm{~m}^{-3}$, consistent with the mixed layer concentrations employed by Mélançon et al. (2014) who used the modeling estimates of Langmann et al. (2010a,b); Chaitén 2008: $0.5 \mathrm{~g} \mathrm{~m}^{-3}$ from the $9 \times 10^{9} \mathrm{~kg}$ ash ocean deposition estimated by Watt et al. (2009) over an area of $7 \times 10^{11} \mathrm{~m}^{2}$ and a mixed layer of $30 \mathrm{~m}$ (de Boyer Montégut et al., 2004); Anatahan 2003: $50 \mathrm{~g} \mathrm{~m}^{-3}$, from the $0.5 \times 10^{10} \mathrm{~kg}$ of ash estimated by Lin et al. (2011) after Trusdell et al. (2005) over the area of apparent satellite detected chlorophyll-a response $\left(4.85 \times 10^{9} \mathrm{~m}^{2}\right)$ and a $20 \mathrm{~m}$ mixed layer (Lin et al., 2011). enrichment experiments, as summarized by Sarmiento et al. (2010).

Calculations were subsequently carried out in the same manner for the eruptions of Mounts Hudson and Pinatubo in 1991 and Kasatochi in 2008. Ocean-bound ash fluxes from Mounts Hudson and Pinatubo in 1991 of 3.25 and 0.004 Pg were calculated from values reported in Watson (1997) and Scasso et al. (1994) respectively, again for the Hudson eruption applying a conservative bulk ash density of 1 ton $\mathrm{m}^{-3}$ to the reported erupted volume. We assumed that the Fe release efficiency was similar to that for the Chaitén ash $\left(1 \times 10^{-6}\right.$ to $1 \times 10^{-5} \mathrm{~g}$ Fe $\left.(\mathrm{g} \mathrm{ash})^{-1}\right)$, producing an Fe flux range of $3.25-32.5 \mathrm{Gg}$ Fe. The Kasatochi 2008 bulk ash flux was estimated at $0.6 \mathrm{Pg}$ after Langmann et al. (2010a,b). Upper and lower Fe release efficiencies for ash from the 2008 Kasatochi eruption, reported by Olgun et al. (2013b), also fall within the same range proposed above for Chaitén ash $\left(3.4 \times 10^{-6}\right.$ to $\left.4.6 \times 10^{-6} \mathrm{~g} \mathrm{Fe}(\mathrm{g} \text { ash })^{-1}\right)$. Thus, using the same range of Fe release efficiency produces a Kasatochi Fe flux range of $0.6-6 \mathrm{Gg}$ Fe.

\section{RESULTS AND DISCUSSION INHERENT OPTICAL PROPERTIES OF CHAITÉN ASH SUSPENDED IN SEAWATER \\ Impact of Chaitén ash on satellite retrieved chlorophyll-a}

Figures 4A,B shows how the $R_{r s}$ (blue) : $R_{r s}$ (green) ratio (here using $\left.R_{r s}(443) / R_{r s}(547)\right)$ and resultant OC3-derived chlorophylla concentrations are impacted by Chaitén ash loading, for three ash concentrations at a range of seawater chlorophyll-a. As has been demonstrated for other mineral particles (e.g. Wozniak and Stramski, 2004), seawater chlorophyll-a concentration is a major factor regulating the relative impact of ash contamination. Chaitén ash is a "pure scatterer" (i.e., its absorption does not vary spectrally); thus the effect of ash addition always has a higher proportional effect on the lower magnitude $R_{r s}$. At low chlorophyll-a concentrations $\left(<1.2 \mathrm{mg} \mathrm{m}^{-3}\right)$ the lower $R_{r s}$ is in the green, thus $R_{r s}$ (green) increases relatively more than $R_{r s}($ blue $)$ subsequent to ash contamination. This has the effect of reducing $R_{r s}($ blue) : $R_{r s}$ (green) and satellite-estimated chlorophyll-a concentrations are accordingly biased upwards. At high seawater chlorophyll-a concentrations $\left(>1.2 \mathrm{mg} \mathrm{m}^{-3}\right.$ ) $R_{r s}$ is lower in the blue (as phytoplankton absorb strongly at this wavelength), thus the relative increase in $R_{r s}$ (blue) is greater than the relative increase in $R_{r s}$ (green). This leads to higher $R_{r s}($ blue $): R_{r s}$ (green) ratio and biases chlorophyll-a concentrations downwards, with the relative magnitude of this bias being much less than for the low (i.e., $<0.5 \mathrm{mg} \mathrm{m}^{-3}$ ) seawater chlorophyll-a concentration scenario. There is a cross-over point at around $1.2 \mathrm{mg}$ chlorophyll-a $\mathrm{m}^{-3}$ where the presence of Chaitén ash exerts no bias on retrieved reflectance ratios and remote sensing estimates of chlorophyll-a. As described above we assumed a spectrally-flat $a_{a s h}^{*}(\lambda)$ value of $0.0001 \mathrm{~m}^{2} \mathrm{~g}^{-1}$; the effect of increasing (reducing) this is to steepen (flatten) the curves of Figure 4 such that bias is greater (lower) at any point apart from the $\mathrm{x}$-intercept.

These calculations only use the inherent optical properties we have measured for Chaitén ash (to our knowledge there have been no such measurements on other volcanic ashes) and significant variability may be expected as the refractive index and particle size spectrum varies for other ash types (see Wozniak and Stramski, 2004). Moreover, even for the same type of ash, size spectra shifts would be expected with distance from source 
as coarser particles fall out of the eruptive plume first. However, these initial results give us a first order indication of the potential impact of a given suspended ash concentration in biasing retrieved chlorophyll-a estimated by conventional Case 1 algorithms. Thus, for the case studies presented in Section: "Remote Sensing of Phytoplankton Response to Ash Deposition," where seawater ash and pre-eruptive chlorophyll-a concentrations can be estimated, we consider the potential bias of suspended ash taking these new findings into account.

\section{Impact of Chaitén ash on light availability for phytoplankton}

The impact of ash on $K_{d}\left(z_{m}, 443 \mathrm{~nm}\right)$ is shown in Figure 4C. As for remote sensing estimates of chlorophyll-a described previously (Section: "Impact of Chaitén Ash on Satellite Retrieved Chlorophyll-a”), the relative impact of ash loading is much greater for low chlorophyll-a waters; e.g., $K_{d}\left(z_{m}, 443 \mathrm{~nm}\right)$ is increased by a factor of $>2$ (or the euphotic depth is more than halved) by high ash loading $\left(>50 \mathrm{~g} \mathrm{~m}^{-3}\right.$ ) when chlorophyll-a is $<0.05 \mathrm{mg}$ $\mathrm{m}^{-3}$ compared with $>0.5 \mathrm{mg} \mathrm{m}^{-3}$. The greater impact of an ash-driven reduction in light availability in oligotrophic waters is significant for interpreting satellite-detected phytoplankton responses to ash because in near-surface waters where remote sensing reflectances predominantly originate, phytoplankton are anticipated to be proximally growth-limited by a nutrient rather than light availability (Moore et al., 2013). Nevertheless, reductions in euphotic depths (i.e., the 1\% light depth) of oligotrophic waters could be significant for phytoplankton populations living at greater depths (e.g., in the sub-surface chlorophyll maximum $(\mathrm{SCM}))$, that are not detected by remote sensing, where the reductions may drive physiological adjustments (i.e., increases in intracellular chlorophyll-a), shifts in community structure, or a shallowing of the SCM. Such shifts could be augmented by any reduction in $K_{d}$ driven by an increase in phytoplankton biomass in shallower waters as a result of nutrient fertilization from the ash.

\section{REMOTE SENSING OF PHYTOPLANKTON RESPONSE TO ASH DEPOSITION \\ HNLC regions}

Mean satellite-derived chlorophyll-a for the month of the Kasatochi 2008 eruption, averaged for a region of ash deposition in the North East Pacific, was reported to be double that for any month since September 1997 (Hamme et al., 2010; Figure 3A; Table 3). Figure 3B shows initial chlorophyll-a concentrations of around $0.5 \mathrm{mg} \mathrm{m}^{-3}$, which at least for the optical properties of the Chaitén ash (Table 2 ), suggest a relatively insignificant biasing of retrieved chlorophyll-a (Figure 4). Furthermore, when we plot the daily resolved chlorophyll growth rate trend we identify the increase at 5 days post-eruption [and therefore $\sim 2-3$ days after expected ash deposition (Langmann et al., 2010a,b)] (Figure 3B), which is (i) consistent with the timescale of chlorophyll-a response observed in mesoscale Fe enrichment experiments performed in the same region (Tsuda et al., 2003; Boyd et al., 2004), and (ii) provides strong qualitative evidence itself of ash particles in the water column not biasing chlorophyll-a concentrations significantly upwards. Eruptions of similar magnitude from Shiveluch (Kamchatka Peninsula, Russia) and Sarychev Peak (Kuril Islands, Russia), also located in the high latitude North Pacific (Figure 1; Table 3), occurred during August 1999 and June 2009 respectively (i.e., summertime, as for Kasatochi 2008), yet our new satellite retrievals show that they produced no observable fertilization. The Shiveluch eruption coincided with onshore southeasterly winds limiting dispersal of ash over low chlorophyll-a regions of the open ocean, whilst images of aerosol loading from the Sarychev Peak eruption resulted in ash deposition over waters previously demonstrated to be Fe-limited in the same season (Tsuda et al., 2003; Fujiki et al., 2014). Unfortunately, any potential remote sensing of phytoplankton response to this latter eruption was prevented due to scarce ocean color coverage in the ash cloud region for 2 weeks subsequent to the event.

Even where detectable, attribution of a satellite-detected chlorophyll-a response to ash deposition without supporting field observations (i.e., Hamme et al., 2010; Achterberg et al., 2013) is difficult. One example is that of a relatively small (VEI 2) eruption of La Cumbre volcano on the Galapagos Islands in 2009. An ash cloud was reported to extend southwest of the island after an eruption on April 11th (Global Volcanism Program, http://www.volcano.si.edu/) into waters typically having elevated nitrate concentrations owing to deep-water upwelling (Figure 1; Table 3). A trio of 8-day chlorophyll-a composites show increasing concentrations to the south west of the volcano a few days after the eruption period (Figure 5). However, attempting to associate these subtle chlorophyll-a increases with sub-areal Fe supply is difficult, with analysis of other satelliteretrieved variables suggesting an alternative or corroboratory role of subsurface Fe supply. Specifically, the development of an increased temperature gradient within the zone of elevated chlorophyll-a between pre-/syn- and post-eruption composites (Figures 5A-C), 10 times enhanced wind stress over background levels on 15th April, and the development of an east-west sea surface height gradient across the islands between the Figures 5A,B time periods (wind and sea surface height data are not shown in the figure; see Section: "Remote Sensing Data" for data access) could be individually or collectively hypothesized to lead to enhanced Fe supply from deeper waters. Similarly, several other events from the same islands (Sierra Negra, October 22nd 2005 eruption; La Cumbre, May 2005 eruptions) displayed no chlorophyll-a responses that could readily be associated with ash deposition (Table 3). Furthermore, the significantly larger VEI 4 eruption of Reventador (Ecuador; see: Figure 1; Table 3) on November 2nd 2002 resulted in ash deposition in the same elevated nitrate eastern Equatorial Pacific region (e.g., Tupper et al., 2006), yet calculating a monthly averaged time series for two regions within the ash fallout area $\left(-85^{\circ} \mathrm{E}\right.$ to $-80^{\circ} \mathrm{E}, 1.5^{\circ} \mathrm{N}$ to $-1.5^{\circ} \mathrm{N}$, representing waters in close proximity to the volcano; and $-95^{\circ} \mathrm{E}$ to $-80^{\circ} \mathrm{E}, 5^{\circ} \mathrm{N}$ to $-5^{\circ} \mathrm{N}$, representing a wider Equatorial Pacific area) indicated chlorophyll-a concentrations for November 2002-December 2002 to be lower (by up to $~ 1 / 3$ ) than the MODIS 2002-2013 climatological average. However, closer inspection of satellite retrieved chlorophyll-a images shortly after the eruption revealed a consistently sparse pixel coverage effectively invalidating any area-averaged time series statistics. 

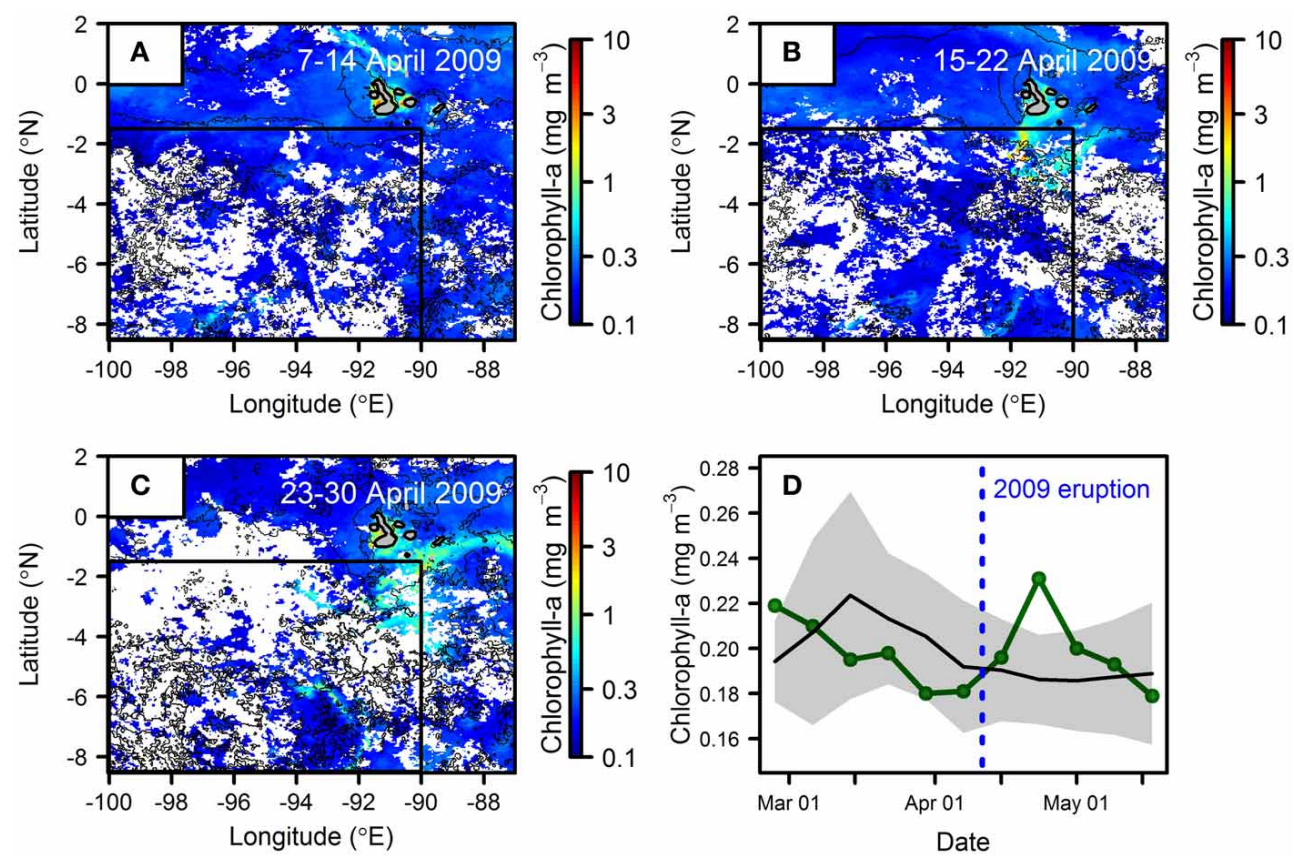

FIGURE 5 | Chlorophyll-a concentrations before and after the 2009 eruption of La Cumbre, Galapagos Islands. (A-C) 8-day chlorophyll-a composites for the time period $(\mathbf{A})$ before, and $\mathbf{( B , C )}$ after the eruption for which an ash cloud was projected to extend westward. Narrow black lines

are $2^{\circ} \mathrm{C}$ temperature contours. (D) Time series of chlorophyll-a averaged over the boxed area in (A-C) for 2009 (green line) and the combined mean average (black line) and standard deviation (gray envelope) for years 2003-2008 and 2010-2013.

Given the status of the Southern Ocean as the largest and biogeochemically most significant HNLC region (e.g., Sigman et al., 2010), biological responses to nutrient enrichment in these waters is of particular interest (Watson, 1997; Boyd et al., 2007; Smetacek et al., 2012; Browning et al., 2014a). Furthermore, active present day South America volcanism almost certainly provides a considerable flux of ash into these waters (Gaiero et al., 2003; Watt et al., 2009). The 2008 eruption of Chaitén (Chile) was of the same scale as the Kasatochi eruption (VEI 4), and its ash cloud could be clearly distinguished as a plume moving eastwards toward the South Atlantic and Southern Ocean (Figure 6A; also, e.g., Watt et al., 2009; Durant et al., 2012). Our analysis of monthly composites of chlorophyll-a for this region revealed much elevated concentrations in waters closely associated with the MalvinasBrazil current confluence and South American shelf (Figure 6B). Furthermore, our measurements of inherent optical properties with this same ash type (see Figure 4) suggest that the baseline chlorophyll-a concentration of $>0.5 \mathrm{mg} \mathrm{m}^{-3}$ in the wider region of deposition (Figure 6B) would not be biasing this observation significantly.

Enhanced chlorophyll-a concentrations in this oceanographic feature in itself is not atypical, driven by interaction of cold, high-nitrate waters of the Malvinas Current with warmer, elevated micronutrient waters in close proximity to the South American shelf break, producing a favorable irradiance-nutrient regime for phytoplankton growth (Gayoso and Podesta, 1996; Brandini et al., 2000; Moore and Abbott, 2000; Garcia et al., 2004; Rivas et al., 2006). However, the satellite-derived chlorophylla concentrations for this zone in May 2008, the month of the

Chaitén eruption (main eruption: 2-10 May), exceeded the 20032013 May climatological average by up to $\sim 45 \mathrm{mg} \mathrm{m}^{-3}$, and $>10 \mathrm{mg} \mathrm{m}^{-3}$ over a wider ocean area (Figure 6D). Inspecting maps of inferred atmospheric aerosol loading suggested the ash deposition area to be to the south of this high chlorophyll-a anomaly (Figure 6A), yet rapid advection of these potentially micronutrient-enriched waters northwards in the Malvinas current could be hypothesized to play some role sustaining this anomalously high phytoplankton stock. When averaged over an area of potential ash deposition for 8-day chlorophyll-a composites before and after the eruption, the 2008 time series also showed the post-eruption period to be elevated relative to a climatological average (Figure 6C); however, a pre-eruption increasing trend suggests an alternative driver for bloom initiation. Moreover, the close association of the anomalous bloom with the dynamic Malvinas current and particularly the shelf break region, where a number of anomalous physical oceanographic phenomena could be hypothesized to alter the growth environment for phytoplankton in this year, once again complicates interpretation of this event from remote sensing data alone.

As for case studies discussed previously, any indication of a response to ash deposition from other South American eruptions is not always either found or readily observable in satellite images. For example, we found that a vigorous explosive eruption of Llaima (Chile) in January 2008, that would have led to light ash deposition in roughly the same region as from the Chaitén 2008 event, was not followed by any apparent response in satellite-retrieved chlorophyll-a (Table 2). This was the case even though the event occurred during mid-austral summer, and thus 

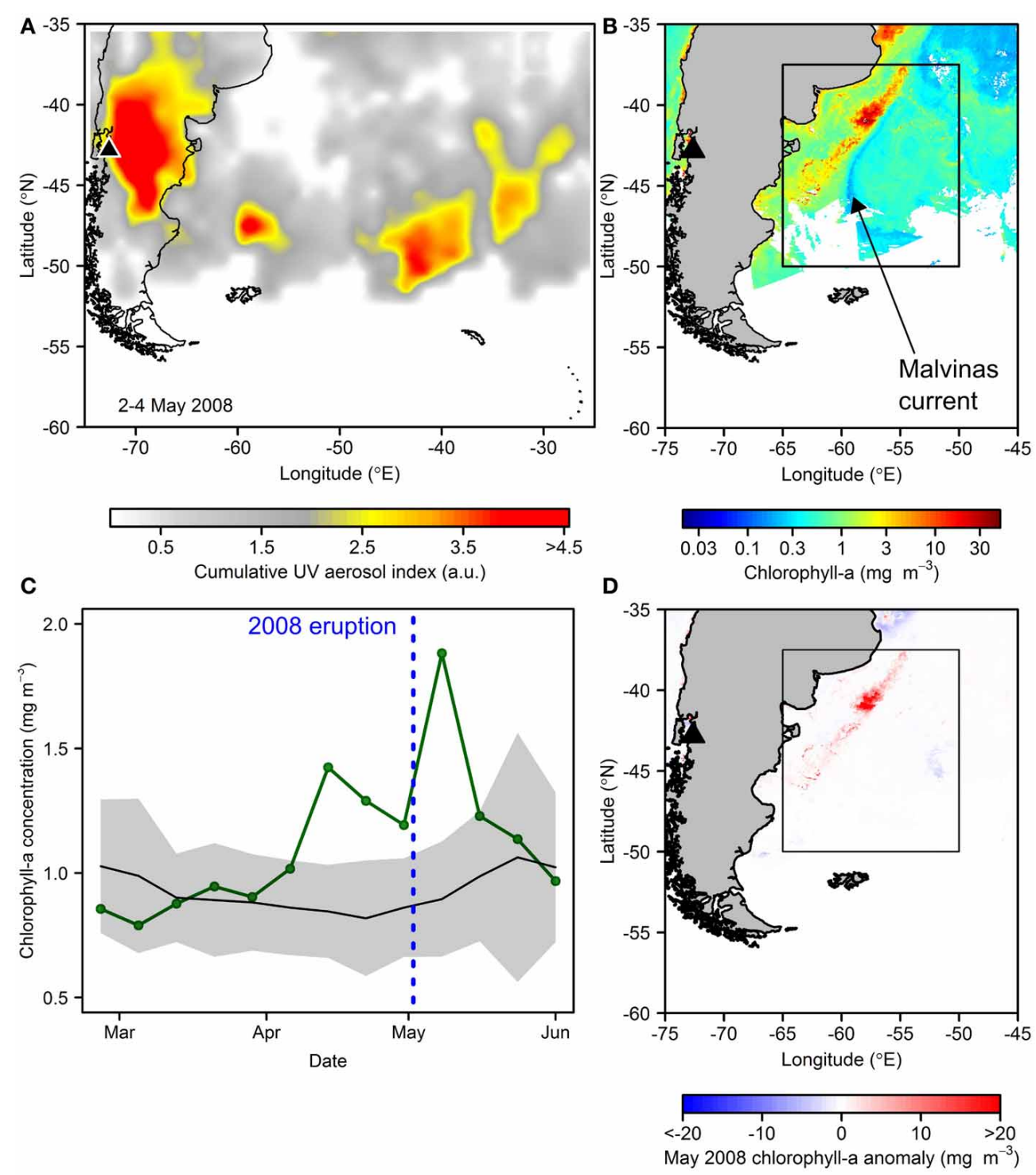

FIGURE 6 | Potential fertilization subsequent to the May 2008 Chaitén eruption. (A) Atmospheric aerosol loading for the main eruption period in May 2008 (product is UV aerosol index from EOS Aura Ozone Measuring Instrument (OMI) summed over 2-4th May 2008). (B) Satellite-derived chlorophyll-a concentrations for May 2008 showing particularly high values associated with the northern Malvinas current. (C) Time series of chlorophyll-a concentrations averaged over an area of expected ash deposition (boxed area in $\mathbf{B}$ ): green line $=2008$; black line and gray shading is 2003-2007, 2009-2013 mean and standard deviation respectively. (D) May 2008 chlorophyll-a anomaly relative to 2003-2013 May average. potentially a time period of elevated Fe stress. If the Chaitén 2008 event indeed had any causative link with the observed enhanced chlorophyll-a biomass in the Argentine Basin, the smaller eruption magnitude (VEI 3) of Llaima 2008 and the resultant lower ash loading could offer an explanation for the absence of any observable satellite-detected chlorophyll-a response to this event. More recently, the Puyehue-Cordón Caulle (PCC) volcano in Chile erupted in June 2011 with a much larger eruption volume than Chaitén or Llaima in 2008 (VEI 5, see Table 3). An ash cloud was observed in images of atmospheric aerosol loading to extend into the South Atlantic and even circumnavigating the globe at $30-55^{\circ} \mathrm{S}$ (e.g., Collini et al., 2013; Figure 7A). Peak ash deposition occurred in winter when light availability was likely the dominant limiting resource for phytoplankton, with Fe stress status uncertain (Boyd, 2002). Furthermore, due to the limited incident solar irradiance at this time of year, satellite-retrieved ocean color data were limited to latitudes north of $45^{\circ} \mathrm{S}$ for July-August. Assessment of short-term (1-2 month) phytoplankton responses in the Southern Ocean was therefore restricted to lower latitudes. Inspection of a time series of 8-day chlorophyll-a composites-averaged zonally over the latitudinal range that both had ocean color coverage and expected ash depositionrevealed a chlorophyll-a increase above that of the climatological mean and standard deviation shortly after the deposition event 
A

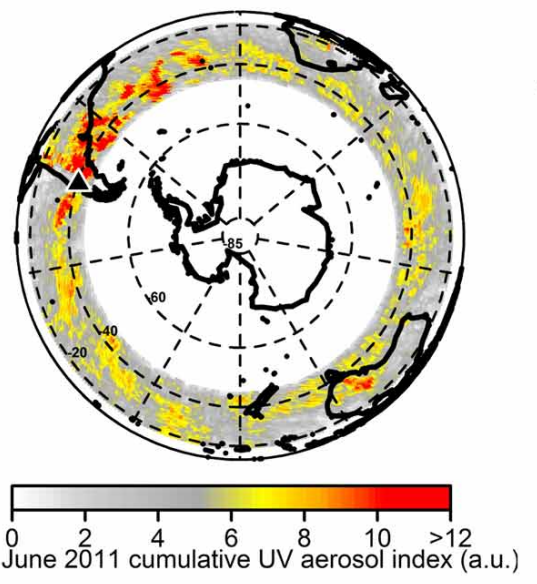

FIGURE 7 | Atmospheric aerosol loading from the Puyehue-Cordón Caulle (PCC) 2011 eruption and limited chlorophyll-a response detected by satellite. (A) Atmospheric aerosol loading for 4-15th June 2011 (UV aerosol index from EOS Aura OMI summed over these dates) showing the

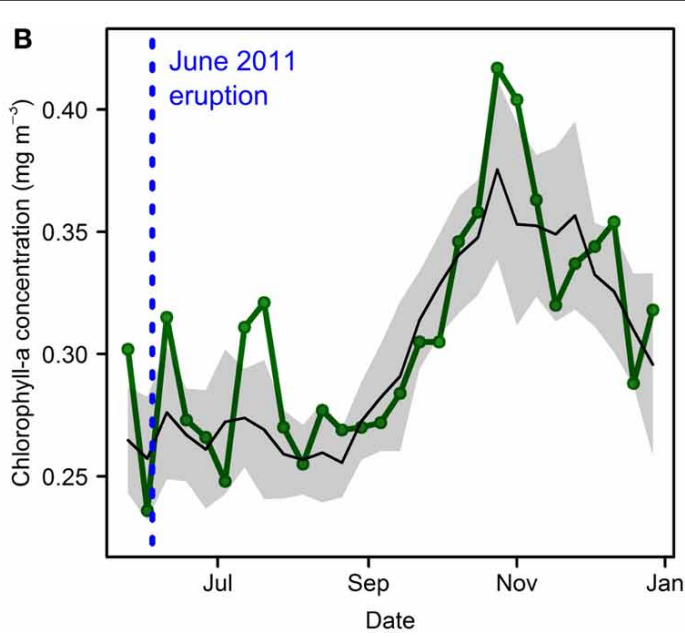

passage of volcanic aerosols around the world at $30-55^{\circ} \mathrm{S}$. (B) Time series of chlorophyll-a concentration averaged zonally over the same latitudinal range (30-55 S) for 2011 (green line), and for the years 2003-2010 and 2012-2013 (mean $=$ black line, standard deviation $=$ gray shading).
(Figure 7B). However, significant subsequent chlorophyll-a variability about the mean indicates that, despite the significant Fe loading anticipated, it is clearly not possible to associate changes in phytoplankton standing stock with ash supply with any degree of confidence.

\section{LNLC regions}

Lin et al. (2011) reported a remote sensing analysis of phytoplankton response in the North Pacific subtropical gyre subsequent to the Anatahan 2003 eruption. Citing prior work suggesting a potential influence of ash on satellite retrieved chlorophyll (Claustre et al., 2002; Duggen et al., 2007), Lin et al. (2011) noted that the observed chlorophyll-a concentration increase of $0.4-0.8 \mathrm{mg} \mathrm{m}^{-3}, 8-16$ times greater than surrounding waters $\left(\sim 0.05 \mathrm{mg} \mathrm{m}^{-3}\right)$, could have been partially biased by ash loading of surface waters. Our optical measurements on Chaitén ash (Figure 4) suggest that, given the low initial chlorophyll concentrations, estimated chlorophyll-a could have been biased on the order of $\sim 10$-fold higher than surrounding waters subsequent to ash contamination; thus having the potential to fully account for the satellite-retrieved chlorophyll anomaly without any increase in phytoplankton biomass (again, this assumes that the optical properties of rhyolitic Chaitén ash are suitable to apply to the brown-gray andesitic Anatahan ash). However, a continued chlorophyll response at a time period $\sim 7$ days after ash deposition, and thus potentially after a significant fraction of ash sinking below surface waters (Duggen et al., 2007), would suggest that this probably not the case.

Uematsu et al. (2004) reported small monthly-averaged satellite-derived chlorophyll-a enhancements $\left(<0.02 \mathrm{mg} \mathrm{m}^{-3}\right)$ in initially oligotrophic waters $\left(<0.08 \mathrm{mg}\right.$ chlorophyll-a $\left.\mathrm{m}^{-3}\right)$ subsequent to the Miyake-jima 2000 eruption (Tables 1, 3). Similarly to Anatahan the optical experiments reported here for Chaitén ash (Figure 4), suggest that, if applicable to basaltic ash, these enhancements could have been driven entirely by ash-mediated changes in ocean color (note that Uematsu et al., 2004, used SeaWiFS images processed using a similar blue:green reflectance ratio algorithm as MODIS).

We carried out an investigation into several additional volcanic ash deposition events in LNLC waters and found no indication of phytoplankton responding to ash supply. For example, the VEI 4 eruption of Ulawun (Papua New Guinea) in 2000 was larger than the Anhatan (2003) eruption reported in the study of Lin et al. (2011), and was coincident with SE winds resulting in ash deposition over near-coastal low chlorophyll waters in the Western Pacific (October 2000 SeaWiFS chlorophyll-a $<0.08 \mathrm{mg} \mathrm{m}^{-3}$ ), yet no clear chlorophyll-a response was readily detectable in satellite images (Table 3). The relatively high anticipated ash flux into low chlorophyll-a waters and no detection of a chlorophyll-a response suggests little ash-driven bias in estimated chlorophyll-a concentrations; indicating either a divergence in optical properties of the basaltic-andesitic Uluwan ash relative to the rhyolitic Chaitén ash we have tested, or a limited residence time of ash in surface waters. A series of explosive (VEI 4) eruptions have occurred in Indonesia and Papua New Guinea since 2002 (Table 3; Figure 1): Ruang (2002); Manam (2004); Rabaul (2006); Merapi (2010); and Kelud (2014). However, the Ruang, Manam, Rabaul eruptions were accompanied by unfavorable winds for seaward ash deposition, and inspection of satellite-derived chlorophyll-a concentrations subsequent to ash deposition from Merapi and Kelud in the west Indian Ocean revealed very poor retrieval of ocean color data in the expected deposition region (presumably due to high incidence of midday cloud cover and potentially the influence of the ash cloud itself) hindering observation of any potential phytoplankton response.

\section{Future directions for remote sensing of phytoplankton responses}

The analysis reported in this section has highlighted difficulties with detecting any potential phytoplankton response to ash deposition events using satellite remote sensing. In a number of cases 
this was due to poorly defined or limited seaward ash deposition, restricted temporal or spatial resolution of satellite coverage, or the potential confounding effect of suspended ash on the optical properties of the water column itself (Table 3). Cases however where chlorophyll-a biomass increases were detected with confidence, for example La Cumbre 2009 (Figure 5), Chaiten 2008 (Figure 6), and Eyjafjallajökull 2010 (Achterberg et al., 2013; Henson et al., 2013), also remain difficult to unambiguously associate with ash nutrient fertilization as a result of multiple potential alternative or additional drivers. Tackling the latter may be aided by continued refinement and ground-truthing of remote sensing methodologies for observing phytoplankton physiology as a less ambiguous measure of nutrient fertilization than changes in phytoplankton biomass (Westberry et al., 2013). Although requiring additional research to begin using with confidence for this purpose, changes in chlorophyll-a fluorescence quantum yields with Fe stress status hold promise (Behrenfeld et al., 2009; Westberry et al., 2013; Browning et al., 2014b). Observing changes in Fe stress could overcome limitations with the use of chlorophyll-a biomass to either elucidate any phytoplankton response to ash deposition where no change in biomass is observed, or to deconvolve the driving mechanism behind an observed biomass response (i.e., a physiological signal of Fe stress recovery followed by a biomass response would be most consistent with ash fertilization). Observing physiological changes that are transitioning more rapidly in response to a transient supply of nutrients than changes in biomass may however require a higher temporal resolution of satellite images that, depending on the region and season of interest, are often not readily available.

\section{CARBON SEQUESTRATION POTENTIAL OF VOLCANIC ASH DEPOSITION EVENTS}

Alongside ash, volcanic eruptions release $\mathrm{CO}_{2}$ into the atmosphere. However, even during periods of increased volcanism the amount is thought to be relatively small on geologically short $\left(10^{3}-10^{4}\right.$ year $)$ timescales and not of great significance in comparison with the atmospheric reservoir of carbon (e.g., Self et al., 2006). Ocean fertilization can increase rates of net organic matter synthesis, which upon sinking to the deep ocean, effectively represents an export of atmospheric carbon (Watson et al., 2000). Accordingly, previous studies have pointed out the potential significance of oceanic volcanic ash fertilization for regulating atmospheric carbon in the past (Spirakis, 1991; Bains et al., 2000; Bay et al., 2004; Cather et al., 2009). Recent observations-both in terms of volcanic ash Fe release experiments and mesoscale Fe enrichments_-provide valuable constraints on evaluating the potential role of volcanic fertilization carbon feedbacks in the earth system.

Extrapolating the $\mathrm{pCO}_{2}$ reduction observed at OSP led Hamme et al. (2010) to estimate an atmospheric drawdown of $\sim 0.01 \mathrm{Pg} \mathrm{C}$ resulting from the Kasatochi 2008 fertilization event, which for comparison represents just $\sim 0.5 \%$ of the anthropogenic $\mathrm{CO}_{2}$ estimated to be taken up each year by the ocean (Manning and Keeling, 2006). Similarly, atmospheric carbon removal subsequent to the Eyjafjallajökull 2010 eruption was suggested to be minimal by Achterberg et al. (2013), the major reason being the relatively modest unutilized macronutrient inventory that typically characterizes the post-bloom condition in the North Atlantic. Thus, in this particular biogeochemical system, any increase in Fe supply would be hypothesized to drive a rapid transition from Fe- to macronutrient-limitation (Ryan-Keogh et al., 2013). Atmospheric carbon removal by the biological pump is expected to scale with macronutrient drawdown (Sigman and Boyle, 2000), thus the high macronutrient waters of the Southern Ocean currently have the greatest potential for carbon sequestration subsequent to volcanic Fe input (Watson, 1997; Browning et al., 2014a).

Volcanoes of present-day southern Chile and Patagonia likely represent a significant fraction of the total volcanic ash flux to the Southern Ocean. Using a volcanic Fe supply of 50-500 Gg from these volcanoes over the past $16.5 \mathrm{kyr}$ (following assumptions in Section: "Calculations of Potential Bounds for Ash-Fertilized Carbon Export"), alongside an empirically constrained range of carbon export efficiencies (Section: "Calculations of Potential Bounds for Ash-Fertilized Carbon Export”), we calculate a Southern Ocean carbon export of $\sim 0.04-15$ Pg C (Figure 8A). This huge range, which accounts for the variability in two poorly constrained parameters (ash Fe release and carbon export efficiencies), highlights the considerable uncertainty that must be taken into account when attempting to evaluate volcanic Fe fertilization in the past (e.g., Bains et al., 2000; Bay et al., 2004; Cather et al., 2009; Jicha et al., 2009; Langmann, 2014). An obvious question is how does the volcanic Fe flux compare with conventional Patagonian dust over the same time period? Given Patagonian dust can itself be remobilized volcanic ash (Watt et al., 2009; Wilson et al., 2011), decoupling the two sources is complicated.

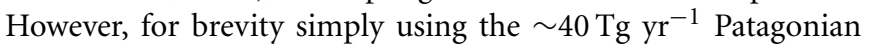
dust flux modeled by Li et al. (2008) alongside bulk Fe contents of $\sim 4 \mathrm{wt} \%$ (Gaiero et al., 2003), an assumption of no interannual variability, and lastly a dust Fe solubility range of $0.2-10 \%$ (after Baker and Croot, 2010), produces an integrated Patagonian dust Fe flux range of $0.05-2.5 \mathrm{Pg}$ Fe for the last $16.5 \mathrm{kyr}$. This is $100-$ 50,000 times greater than that of our (conservative) estimate for Patagonian volcanic Fe.

Refining estimates of Fe release and carbon export efficiencies could be aided by detailed observations of contemporary eruptions. Mount Hudson erupted in 1991 resulting in heavy ash fallout in the South Atlantic and Southern Ocean (Figure 9; Gaiero et al., 2003), with Fe supply from this single eruption calculated as $\sim 6.5 \%$ that of our conservative estimate of 16.5 kyr-present day volcanic fluxes (see Section: "Calculations of Potential Bounds for Ash-Fertilized Carbon Export"). The eruption occurred in mid-austral winter (August) when phytoplankton in Southern Ocean waters are limited to first order by light availability (Boyd, 2002). However, much of the deposited Fe could well have been transported north, either in the Malvinas current or the northerly limb of the Antarctic Circumpolar Current (ACC), reaching the Atlantic subtropical frontal zone by austral spring-summertime. This frontal zone is host to Fe-stressed phytoplankton in austral summer (Browning et al., 2014c), likely making it highly sensitive to pre-bloom micronutrient loading. No ocean color sensors were in operation at this time but records of $\mathrm{O}_{2} / \mathrm{N}_{2}$ in both hemispheres indicate an $\mathrm{O}_{2}$ pulse from southern hemisphere oceans, and thus enhanced 

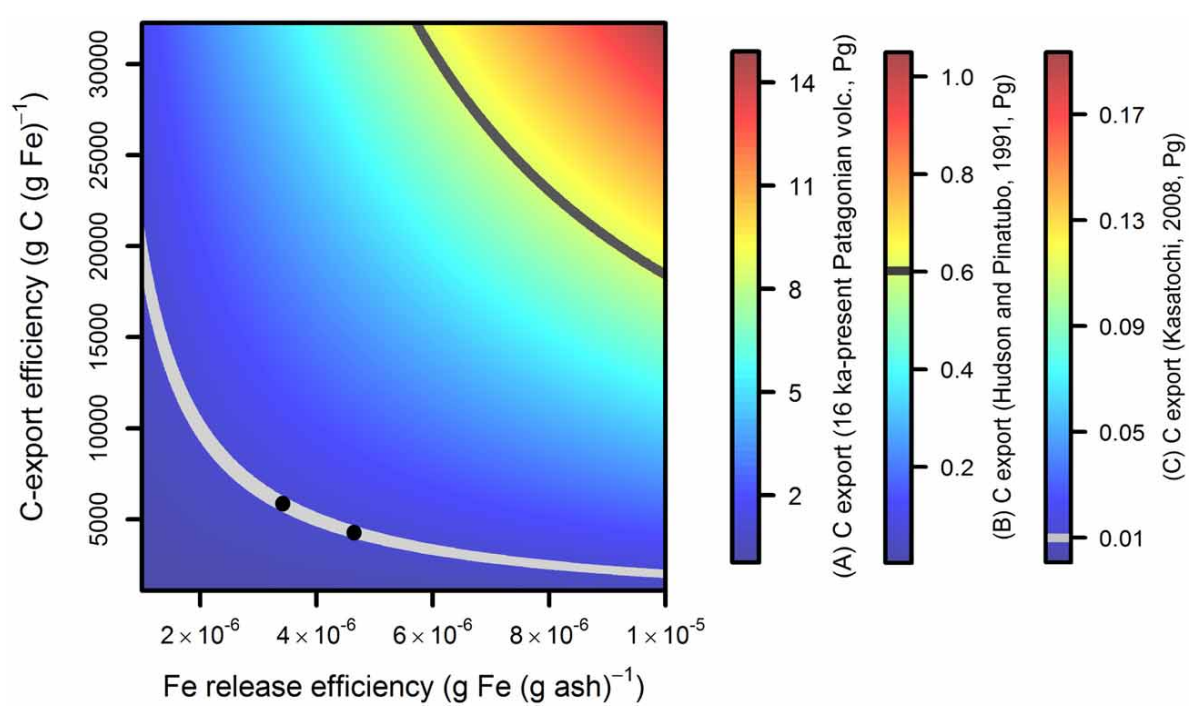

FIGURE 8 | Potential range of carbon sequestration calculated for applied bounds of Fe release from ash and carbon sequestration efficiency-highlighting the substantial uncertainty in estimating the potential for ash fertilization-induced carbon export. Ranges of $\mathrm{Fe}$ release and carbon sequestration efficiencies are described in Section: "Calculations of Potential Bounds for Ash-Fertilized Carbon Export." These ranges have been applied to three estimates of ash fluxes to HNLC waters: (A) the $16.5 \mathrm{kyr}$ to present day flux to the Southern Ocean; (B) the 1991 eruptions of Pinatubo and Hudson; and (C) the 2008 Kasatochi eruption. Gray lines on the main figure and $(\mathbf{B}, \mathbf{C})$ correspond to the carbon export that would produce (i) the observed $\mathrm{O}_{2}$ pulse from southern hemisphere oceans in 1991/1992 subsequent to the Hudson and Pinatubo events (Keeling et al., 1996) (dark gray); and (ii) the extrapolated surface ocean dissolved $\mathrm{pCO}_{2}$ reduction at Ocean Station Papa subsequent to the Kasatochi event (Hamme et al., 2010) (light gray). Black dots on the Kasatochi curve correspond to upper and lower Fe release bounds measured from Kasatochi ash by Olgun et al. (2013b) (reported as $\left.61-83 \mathrm{nmol} F \mathrm{Fe}(\mathrm{g} \mathrm{ash})^{-1}\right)$.

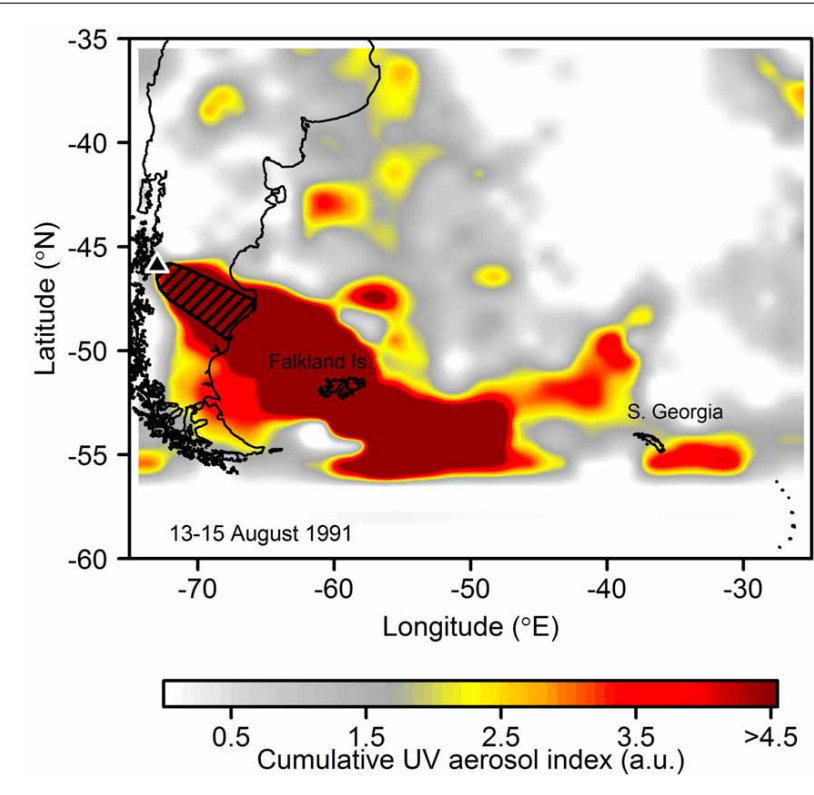

FIGURE 9 | Atmospheric aerosol loading for the main eruption period of Mount Hudson in August 1991 (product is UV aerosol index from Nimbus-7 Total Ozone Mapping Spectrometer (TOMS) summed over 13-15th May 1991) suggestive of significant ash deposition into the South West Atlantic and Scotia Sea. Hudson is identified with a black triangle. The hatched region shows the $>10 \mathrm{~mm}$ isopach (ash thickness) for the eruption which has been mapped out on land (Scasso et al., 1994). Ash deposits from the eruption have been found deposited on the Falkland Islands (Kratzmann et al., 2010) and South Georgia (Smellie, 1999). ocean primary productivity in these waters, during austral summer 1991/1992 (Keeling et al., 1996; Watson, 1997). This has previously been linked with Fe fertilization from the June 1991 eruption of Mt Pinatubo alone (Watson, 1997). Pinatubo is located in the northern hemisphere (Figure 1), and as noted by Langmann et al. (2010a) and Langmann (2014), considerably less ash fallout in the Southern Ocean occurred for this event.

Accordingly, performing a carbon export calculation (Section: "Calculations of Potential Bounds for Ash-Fertilized Carbon Export") based on the erupted ash mass reaching the Southern Ocean from both Pinatubo and Hudson in 1991, produces a range of $\sim 0.003-1$ Pg C (Figure 8B). Falling within our uncertainty range, an anomalous carbon export of $\sim 0.6$ Pg driven by enhanced Fe fertilization would have been required to account for the whole reported $\sim 10^{14}$ mole $\mathrm{O}_{2}$ pulse from southern hemisphere oceans in this year (Keeling et al., 1996; dark gray line on Figure 8B). Performing similar calculations, a carbon sink of $\sim 0.01 \mathrm{Pg}$ C from the Kasatochi 2008 eruption (extrapolated from direct measurements, Hamme et al., 2010), for an estimated eruption mass of $\sim 0.6 \mathrm{Pg}$ (Langmann et al., 2010a,b), offers additional potential constraint on Fe release and carbon export efficiencies (Figure 8C). Moreover, if the results of recent leaching experiments performed on Kasatochi ash by Olgun et al. (2013b) can realistically be applied (see Baker and Croot, 2010), carbon sequestration efficiency can potentially be narrowed down to $\sim 5000 \mathrm{~g} \mathrm{C}(\mathrm{g} \mathrm{Fe})^{-1}$ for this Fe enrichment (Figure 8).

We have used simple calculations to estimate volcanic Fe supply from Patagonia to be $100-50,000$ times lower than that of dust estimates over long (>10 kyr) timescales. In addition to 
total fluxes, differences in modes of delivery could be particularly important for Southern Ocean biogeochemistry. Volcanic deposition is dominated by transient pulses whereas dust supply is somewhat more continuous; the former likely leading to both reduced Fe release and carbon export efficiencies than continuous low-level supply (Baker and Croot, 2010; Le Moigne et al., 2014). Thus, on thousands of year timescales, ash-fertilized carbon export from Patagonian volcanism is likely orders of magnitude lower than dust, whilst individual eruptions could likely feature significantly at the interannual scale. This issue of timescale will be important to recognize in any future carbon cycle modeling that includes volcanic Fe fluxes to the ocean.

\section{CONCLUSIONS AND FUTURE DIRECTIONS}

- Bottle-scale ash enrichment experiments and observations of a suite of biogeochemical parameters subsequent to two recent ash deposition events have demonstrated phytoplankton responses in three seasonally Fe-limited regions (high latitude North Atlantic: Achterberg et al., 2013; North Pacific: Hamme et al., 2010; Mélançon et al., 2014; Southern Ocean: Browning et al., 2014a). Recorded responses to ash have been similar (Mélançon et al., 2014), smaller (Achterberg et al., 2013), or greater than (Browning et al., 2014a) that of Feonly enrichments. From the limited observations available, these differences appear to depend more on the biogeochemical system rather than particular ash type. Remote sensing of an eruption in the highly-oligotrophic macronutrient-limited subtropical Pacific has provided evidence for the stimulation of a phytoplankton bloom (Lin et al., 2011), consistent with recent field observations of large-scale biogeochemical patterns responding to dust deposition in the (sub)tropical North Atlantic (Schlosser et al., 2014).

- Measurements of inherent optical properties of Chaitén ash suspended in seawater suggest that satellite-retrieved chlorophyll-a concentrations can be biased high by greater than an order of magnitude. The magnitude and sign of bias is however highly sensitive to the respective ash loading and initial seawater chlorophyll-a concentration. Experiments of inherent optical properties for other ash types including ranges of ash particle size spectra, alongside an improved sensitivity for measuring the magnitude and spectral variability of light absorption by ash are needed to better constrain biasing by ash-loading for chlorophyll-a estimated using current Case 1 ocean color algorithms. Beyond a simple adjustment of routine Case 1 algorithms, new algorithms similar to those being developed for optically complex Case 2 waters (Odermatt et al., 2012) could be investigated as a more rigorous means for accurate chlorophyll-a retrieval. Such algorithms could make use of the greater range of wavebands available on current and future ocean color sensors for isolating ash signals.

- Phytoplankton responses to ash deposition are not consistently observed using remote sensing. Often poor temporal and spatial satellite coverage during an expected response period may simply be preventing detection, yet there are multiple factors responsible for regulating the phytoplankton standing crop that should be anticipated to potentially result in the absence of biomass increase subsequent to a nutrient enrichment event (Cullen et al., 1992; Boyd et al., 2010). Continuous low-level input of ash through small, regular eruptions likely fertilizes phytoplankton to some extent, potentially with greater efficiency (Baker and Croot, 2010; Le Moigne et al., 2014), although responses to these can be difficult to identify using remote sensing. New algorithms relating subtle changes in chlorophyll-a biomass (e.g., over baseline averages) to potential nutrient supply could offer a means to better resolve these (O’Malley et al., 2014).

- Continued refinement and ground-truthing of remote sensing methodologies for observing phytoplankton physiology as a less ambiguous measure of nutrient fertilization than phytoplankton biomass may better enable detected responses to be causatively associated with a transient ash deposition event. For example, changes in chlorophyll-a fluorescence quantum yields with Fe stress status (Behrenfeld et al., 2009; Westberry et al., 2013; Browning et al., 2014b) could overcome limitations with the use of chlorophyll-a biomass to elucidate any phytoplankton response to ash deposition or to deconvolve the driving mechanism behind any biomass response. Improvements in quantitatively estimating ash concentrations in eruption plumes using remote sensing will help refine estimates of ash fluxes to the ocean (e.g., Prata and Prata, 2012; Webster et al., 2012).

- Volcanic eruptions have the potential to cause regional or even global-scale Fe-fertilization (e.g., Duggen et al., 2010; Langmann, 2014). However, whilst the ecological consequences of such fertilization events will almost certainly be large, there is much uncertainty with regard to potential atmospheric carbon sequestration from these.

- Carefully designed experiments detecting metal release from ash using conditions that best replicate, or ideally utilize, the natural ocean will be an invaluable resource for constraining the fertilization potential of eruptions. Following the lead of studies performing leaching experiments on regular desert dust (e.g., Baker and Croot, 2010), such experiments should also pay careful consideration to ash particle size, ash-loading, and exposure time to best mimic natural ash depositions in the oceanic regime of interest (i.e., coastal vs. open ocean waters) (Duggen et al., 2010).

- Large-scale ash deposition events potentially provide a useful platform to assess the response of a biogeochemical system to relief of micronutrient stress (Hamme et al., 2010; Achterberg et al., 2013). With better characterization of micronutrient release, such events could be perhaps be more suited to this purpose than dust deposition, as eruptions are point sourced and contain diagnostic gasses, aiding identification of event and response using remote sensing. Given the often sporadic and remote nature of eruptions and ash deposition, sensors on autonomous platforms (Johnson et al., 2009; Hamme et al., 2010) could be essential in providing the independent ground observations needed to compliment remote sensing in detecting and quantifying biogeochemical responses. The international oceanographic community might also wish to consider putting contingency plans in place in order to be able to respond rapidly with a full suite of relevant biogeochemical measurements to any eruption event that is within reach of any fortuitously located research vessel. 


\section{AUTHOR CONTRIBUTIONS}

All authors contributed to the project design. KS and VV performed the ash optics experiments. TB and VV analyzed the ash optics data. TB and $\mathrm{KS}$ performed the remote sensing analysis. TB synthesized the review material and wrote the initial draft of the paper and all authors contributed to its revision.

\section{ACKNOWLEDGMENTS}

TB and $\mathrm{HB}$ acknowledge funding from the NERC UKGEOTRACES consortium grant (NE/H006095/1, which included a studentship to TB). TM and DP acknowledge funding from NERC (NCEO/COMET, and NERC grant NE/I013210/1). TM further acknowledges funding from the Leverhulme trust. VV acknowledges funding from a PML RP and ADEPT. Sebastian Watt is thanked for collecting the Chaitén 2008 ash sample. Gemma Prata and Ben Reed are thanked for providing unpublished refractive indices for this ash. Peter Land is thanked for helpful discussions relating to the influence of suspended ash on satellite retrieved chlorophyll-a. The two reviewers are thanked for providing recommendations that much improved an earlier version of this manuscript.

\section{REFERENCES}

Abraham, E. R. (1998). The generation of plankton patchiness by turbulent stirring. Nature 391, 577-580. doi: 10.1038/35361

Abraham, E. R., Law, C. S., Boyd, P. W., Lavender, S. J., Maldonado, M. T., and Bowie, A. R. (2000). Importance of stirring in the development of an iron-fertilized phytoplankton bloom. Nature 407, 727-730. doi: 10.1038/35 037555

Achterberg, E. P., Moore, C. M., Henson, S. A., Steigenberger, S., Stohl, A., Eckhardt, S., et al. (2013). Natural iron fertilization by the Eyjafjallajokull volcanic eruption. Geophys. Res. Lett. 40, 921-926. doi: 10.1002/grl.50221

Ayris, P., and Delmelle, P. (2012). Volcanic and atmospheric controls on ash iron solubility: a review. Phys. Chem. Earth 45-46, 103-112. doi: 10.1016/j.pce.2011.04.013

Babin, M., and Stramski, D. (2004). Variations in the mass-specific absorption coefficient of mineral particles suspended in water. Limnol. Oceanogr. 49, 756-767. doi: 10.4319/lo.2004.49.3.0756

Baines, P. G., and Sparks, R. S. J. (2005). Dynamics of giant volcanic ash clouds from supervolcanic eruptions. Geophys. Res. Lett. 32. doi: 10.1029/2005gl024597

Bains, S., Norris, R. D., Corfield, R. M., and Faul, K. L. (2000). Termination of global warmth at the Palaeocene/Eocene boundary through productivity feedback. Nature 407, 171-174. doi: 10.1038/35025035

Baker, A. R., and Croot, P. L. (2010). Atmospheric and marine controls on aerosol iron solubility in seawater. Mar. Chem.120, 4-13. doi: 10.1016/j.marchem.2008.09.003

Banse, K. (1992). Grazing, temporal changes of phytoplankton concentrations, and the microbial loop in the open sea. Prim. Prod. Biogeoch. Cycles Sea 43, 409-440. doi: 10.1007/978-1-4899-0762-2_22

Bay, R. C., Bramall, N., and Price, P. B. (2004). Bipolar correlation of volcanism with millennial climate change. Proc. Natl. Acad. Sci. U.S.A. 101, 6341-6345. doi: $10.1073 /$ pnas. 0400323101

Behrenfeld, M. J. (2010). Abandoning Sverdrup's Critical Depth Hypothesis on phytoplankton blooms. Ecology 91, 977-989. doi: 10.1890/09-1207.1

Behrenfeld, M. J., Doney, S. C., Lima, I., Boss, E. S., and Siegel, D. A. (2013). Annual cycles of ecological disturbance and recovery underlying the subarctic Atlantic spring plankton bloom. Glob. Biogeochem. Cycles 27, 526-540. doi: $10.1002 / g b c .20050$

Behrenfeld, M. J., and Milligan, A. J. (2013). photophysiological expressions of iron stress in phytoplankton. Annu. Rev. Mar. Sci. 5, 217-246. doi: 10.1146/annurevmarine-121211-172356

Behrenfeld, M. J., Westberry, T. K., Boss, E. S., O’Malley, R. T., Siegel, D. A., Wiggert, J. D., et al. (2009). Satellite-detected fluorescence reveals global physiology of ocean phytoplankton. Biogeosciences 6, 779-794. doi: 10.5194/bg-6-779-2009
Berman-Frank, I., Cullen, J. T., Shaked, Y., Sherrell, R. M., and Falkowski, P. G. (2001). Iron availability, cellular iron quotas, and nitrogen fixation in Trichodesmium. Limnol. Oceanogr. 46, 1249-1260. doi: 10.4319/lo.2001.46. 6.1249

Bonnet, S., Guieu, C., Bruyant, F., Prasil, O., Van Wambeke, F., Raimbault, P., et al. (2008). Nutrient limitation of primary productivity in the Southeast Pacific (BIOSOPE cruise). Biogeosciences 5, 215-225. doi: 10.5194/bg-5-215-2008

Boyd, P. W. (2002). Environmental factors controlling phytoplankton processes in the Southern Ocean. J. Phycol. 38, 844-861. doi: 10.1046/j.1529-8817.2002.t011-01203.x

Boyd, P. W., and Ellwood, M. J. (2010). The biogeochemical cycle of iron in the ocean. Nat. Geosci. 3, 675-682. doi: 10.1038/ngeo964

Boyd, P. W., Jickells, T., Law, C. S., Blain, S., Boyle, E. A., Buesseler, K. O., et al. (2007). Mesoscale iron enrichment experiments 1993-2005: synthesis and future directions. Science 315, 612-617. doi: 10.1126/science.1131669

Boyd, P. W., Law, C. S., Wong, C. S., Nojiri, Y., Tsuda, A., Levasseur, M., et al. (2004). The decline and fate of an iron-induced subarctic phytoplankton bloom. Nature 428, 549-553. doi: 10.1038/nature02437

Boyd, P. W., Mackie, D. S., and Hunter, K. A. (2010). Aerosol iron deposition to the surface ocean-modes of iron supply and biological responses. Mar. Chem. 120, 128-143. doi: 10.1016/j.marchem.2009.01.008

Boyd, P. W., Strzepek, R., Chiswell, S., Chang, H., Debruyn, J. M., Ellwood, M., et al. (2012). Microbial control of diatom bloom dynamics in the open ocean. Geophys. Res. Lett. 39:L18601. doi: 10.1029/2012gl053448

Brandini, F. P., Boltovskoy, D., Piola, A., Kocmur, S., Rottgers, R., Abreu, P. C., et al. (2000). Multiannual trends in fronts and distribution of nutrients and chlorophyll in the southwestern Atlantic (30-62 degrees S). Deep Sea Res. I 47, 1015-1033. doi: 10.1016/S0967-0637(99)00075-8

Browning, T. J., Bouman, H. A., Henderson, G. M., Mather, T. A., Pyle, D. M., Schlosser, C., et al. (2014a). Strong responses of Southern Ocean phytoplankton communities to volcanic ash. Geophys. Res. Lett. 41, 2851-2857. doi: 10.1002/2014GL059364

Browning, T. J., Bouman, H. A., and Moore, C. M. (2014b). Satellite-detected fluorescence: decoupling nonphotochemical quenching from iron stress signals in the South Atlantic and Southern Ocean. Glob. Biogeochem. Cycles 28, 510-524. doi: 10.1002/2013GB004773

Browning, T. J., Bouman, H. A., Moore, C. M., Schlosser, C., Tarran, G. A., Woodward, E. M. S., et al. (2014c). Nutrient regimes control phytoplankton ecophysiology in the South Atlantic. Biogeosciences 11, 463-479. doi: 10.5194/bg-11-463-2014

Cather, S. M., Dunbar, N. W., McDowell, F. W., McIntosh, W. C., and Scholle, P. A. (2009). Climate forcing by iron fertilization from repeated ignimbrite eruptions: the icehouse-silicic large igneous province (SLIP) hypothesis. Geosphere 5, 315-324. doi: 10.1130/GES00188.1

Censi, P., Randazzo, L. A., Zuddas, P., Saiano, F., Arico, P., and Ando, S. (2010). Trace element behaviour in seawater during Etna's pyroclastic activity in 2001: concurrent effects of nutrients and formation of alteration minerals. J. Volcanol. Geoth. Res. 193, 106-116. doi: 10.1016/j.jvolgeores.2010.03.010

Claustre, H., Morel, A., Hooker, S. B., Babin, M., Antoine, D., Oubelkheir, K. et al. (2002). Is desert dust making oligotrophic waters greener? Geophys. Res. Lett. 29, 107-1-107-4. doi: 10.1029/2001GL014056

Collini, E., Osores, M. S., Folch, A., Viramonte, J. G., Villarosa, G., and Salmuni, G. (2013). Volcanic ash forecast during the June 2011 Cordon Caulle eruption. Nat. Hazards 66, 389-412. doi: 10.1007/s11069-012-0492-y

Cullen, J. J. (1982). The deep chlorophyll maximum—comparing vertical profiles of chlorophyll-a. Can. J. Fish. Aquat. Sci. 39, 791-803. doi: 10.1139/f82-108

Cullen, J. J. (1991). Hypotheses to explain high-nutrient conditions in the open Sea. Limnol. Oceanogr. 36, 1578-1599. doi: 10.4319/lo.1991.36.8.1578

Cullen, J. J., Yang, X. L., and Macintyre, H. L. (1992). Nutrient limitation of marine photosynthesis. Prim. Prod. Biogeochem. Cycles Sea 43, 69-88. doi: 10.1007/9781-4899-0762-2_5

Dall'Olmo, G., Westberry, T. K., Behrenfeld, M. J., Boss, E., and Slade, W. H. (2009). Significant contribution of large particles to optical backscattering in the open ocean. Biogeosciences 6, 947-967. doi: 10.5194/bg-6-947-2009

De Baar, H. J. W., Boyd, P. W., Coale, K. H., Landry, M. R., Tsuda, A., Assmy, P., et al. (2005). Synthesis of iron fertilization experiments: from the iron age in the age of enlightenment. J. Geophys. Res. Oceans 110. doi: 10.1029/2004jc002601

de Boyer Montégut, C., Madec, G., Fischer, A. S., Lazar, A., and Iudicone, D. (2004). Mixed layer depth over the global ocean: an examination of profile 
data and a profile-based climatology. J. Geophys. Res. 109. doi: 10.1029/2004JC 002378

Delmelle, P., Lambert, M., Dufrene, Y., Gerin, P., and Oskarsson, N. (2007). Gas/aerosol-ash interaction in volcanic plumes: new insights from surface analyses of fine ash particles. Earth Planet. Sci. Lett. 259, 159-170. doi: 10.1016/j.epsl.2007.04.052

DiTullio, G. R., and Laws, E. A. (1991). Impact of an atmospheric-oceanic disturbance on phytoplankton community dynamics in the North Pacific Central Gyre. Deep-Sea Res. A 38, 1305-1329. doi: 10.1016/0198-0149(91)90029-F

Duffy, J. E., and Stachowicz, J. J. (2006). Why biodiversity is important to oceanography: potential roles of genetic, species, and trophic diversity in pelagic ecosystem processes. Mar. Ecol. Prog. Ser. 311, 179-189. doi: 10.3354/meps311179

Duggen, S., Croot, P., Schacht, U., and Hoffmann, L. (2007). Subduction zone volcanic ash can fertilize the surface ocean and stimulate phytoplankton growth: evidence from biogeochemical experiments and satellite data. Geophys. Res. Lett. 34. doi: $10.1029 / 2006 \mathrm{gl} 027522$

Duggen, S., Olgun, N., Croot, P., Hoffmann, L., Dietze, H., Delmelle, P., et al. (2010). The role of airborne volcanic ash for the surface ocean biogeochemical iron-cycle: a review. Biogeosciences 7, 827-844. doi: 10.5194/bg-7-827-2010

Durant, A. J., Villarosa, G., Rose, W. I., Delmelle, P., Prata, A. J., and Viramonte, J. G. (2012). Long-range volcanic ash transport and fallout during the 2008 eruption of Chaiten volcano, Chile. Phys. Chem. Earth 45-46, 50-64. doi: 10.1016/j.pce.2011.09.004

Falkowski, P. G. (1997). Evolution of the nitrogen cycle and its influence on the biological sequestration of $\mathrm{CO} 2$ in the ocean. Nature 387, 272-275. doi: $10.1038 / 387272 \mathrm{a} 0$

Falkowski, P. G., Barber, R. T., and Smetacek, V. (1998). Biogeochemical controls and feedbacks on ocean primary production. Science 281, 200-206. doi: 10.1126/science.281.5374.200

Fontijn, K., Lachowycz, S. M., Rawson, H., Pyle, D. M., Mather, T. A., Naranjo, J. A., et al. (2014). Late Quaternary tephrostratigraphy of southern Chile and Argentina. Quat. Sci. Rev. 89, 70-84. doi: 10.1016/j.quascirev.2014.02.007

Frogner, P., Gislason, S. R., and Oskarsson, N. (2001). Fertilizing potential of volcanic ash in ocean surface water. Geology 29, 487-490. doi: 10.1130/00917613(2001)029<0487:FPOVAI > 2.0.CO;2

Fujiki, T., Matsumoto, K., Mino, Y., Sasaoka, K., Wakita, M., Kawakami, H., et al. (2014). Seasonal cycle of phytoplankton community structure and photophysiological state in the western subarctic gyre of the North Pacific. Limnol. Oceanogr. 59, 887-900. doi: 10.4319/lo.2014.59.3.0887

Gaiero, D. M., Probst, J. L., Depetris, P. J., Bidart, S. M., and Leleyter, L. (2003). Iron and other transition metals in Patagonian riverborne and windborne materials: geochemical control and transport to the southern South Atlantic Ocean. Geochim. Cosmochim. Acta 67, 3603-3623. doi: 10.1016/S0016-7037(03) 00211-4

Garcia, C. A. E., Sarma, Y. V. B., Mata, M. M., and Garcia, V.M.T. (2004), Chlorophyll variability and eddies in the Brazil-Malvinas Confluence region. Deep Sea Res. II 51, 159-172. doi: 10.1016/j.dsr2.2003.07.016

Gayoso, A. M., and Podesta, G. P. (1996). Surface hydrography and phytoplankton of the Brazil-Malvinas currents confluence. J. Plankton. Res. 18, 941-951. doi: 10.1093/plankt/18.6.941

Geider, R. J. (1987). Light and temperature-dependence of the carbon to chlorophyll-a ratio in microalgae and cyanobacteria-implications for physiology and growth of phytoplankton. New Phytol. 106, 1-34. doi: 10.1111/j.14698137.1987.tb04788.x

Gordon, H. R., and Morel, A. Y. (1983). Remote Assessment of Ocean Color for Interpretation of Satellite Visible Imagery: A Review. New York, NY: SpringerVerlag.

Hamme, R. C., Webley, P. W., Crawford, W. R., Whitney, F. A., Degrandpre, M. D., Emerson, S. R., et al. (2010). Volcanic ash fuels anomalous plankton bloom in subarctic northeast Pacific. Geophys. Res. Lett. 37. doi: 10.1029/2010gl 044629

Henderson, G. M., Anderson, R. F., Adkins, J., Andersson, P., Boyle, E. A., Cutter, G., et al. (2007). GEOTRACES-an international study of the global marine biogeochemical cycles of trace elements and their isotopes. Chem. Der Erde Geochem. 67, 85-131. doi: 10.1016/j.chemer.2007.02.001

Henson, S. A., Painter, S. C., Holliday, N. P., Stinchcombe, M. C., and Giering, S. L. C. (2013). Unusual subpolar North Atlantic phytoplankton bloom in 2010: volcanic fertilization or North Atlantic Oscillation? J. Geophy. Res. Oceans 118, 4771-4780. doi: 10.1002/jgrc.20363
Hoffmann, L. J., Breitbarth, E., Ardelan, M. V., Duggen, S., Olgun, N., Hassellov, M., et al. (2012). Influence of trace metal release from volcanic ash on growth of Thalassiosira pseudonana and Emiliania huxleyi. Mar. Chem. 132, 28-33. doi: 10.1016/j.marchem.2012.02.003

Jicha, B. R., Scholl, D. W., and Rea, D. K. (2009). Circum-Pacific arc flare-ups and global cooling near the Eocene-Oligocene boundary. Geology 37, 303-306. doi: 10.1130/G25392A.1

Johnson, K. S., Berelson, W. M., Boss, E., Chase, Z., Claustre, H., Emerson, S. R., et al. (2009). Observing biogeochemical cycles at global scales with profiling floats and gliders prospects for a global array. Oceanography 22, 216. doi: 10.5670/oceanog.2009.81

Johnson, K. S., Elrod, V. A., Fitzwater, S. E., Plant, J. N., Chavez, F. P., Tanner, S. J., et al. (2003). Surface ocean-lower atmosphere interactions in the Northeast Pacific Ocean Gyre: aerosols, iron, and the ecosystem response. Glob. Biogeochem. Cycles 17. doi: 10.1029/2002GB002004

Johnson, K. S., Gordon, R. M., and Coale, K. H. (1997). What controls dissolved iron concentrations in the world ocean? Mar. Chem. 57, 137-161. doi 10.1016/S0304-4203(97)00043-1

Jones, M. T., and Gislason, S. R. (2008). Rapid releases of metal salts and nutrients following the deposition of volcanic ash into aqueous environments. Geochim. Cosmochim. Acta 72, 3661-3680. doi: 10.1016/j.gca.2008.05.030

Keeling, R. F., Piper, S. C., and Heimann, M. (1996). Global and hemispheric $\mathrm{CO}_{2}$ sinks deduced from changes in atmospheric O-2 concentration. Nature 381, 218-221. doi: $10.1038 / 381218 \mathrm{a} 0$

Keeling, R. F., and Shertz, S. R. (1992). Seasonal and interannual variations in atmospheric oxygen and implications for the global carbon-cycle. Nature 358, 723-727. doi: 10.1038/358723a0

Kirk, J. T. O. (1981). Monte Carlo study of the nature of the underwater light field in, and the relationships between optical properties of, turbid yellow waters. Mar. Freshwater Res. 32, 517-532. doi: 10.1071/MF9810517

Kratzmann, D. J., Carey, S. N., Fero, J., Scasso, R. A., and Naranjo, J. A. (2010). Simulations of tephra dispersal from the 1991 explosive eruptions of Hudson volcano, Chile. J. Volcanol. Geoth. Res. 190, 337-352. doi: 10.1016/j.jvolgeores.2009.11.021

Kump, L. R., Kasting, J. F., and Crane, R. G. (1999). The Earth System, Vol. 432. New Jersey, NJ: Prentice Hall.

Landry, M. R., Constantinou, J., Latasa, M., Brown, S. L., Bidigare, R. R., and Ondrusek, M. E. (2000). Biological response to iron fertilization in the eastern equatorial Pacific (IronEx II). III. Dynamics of phytoplankton growth and microzooplankton grazing. Mar. Ecol. Prog. Ser. 201, 57-72. doi: 10.3354/meps201057

Landry, M. R., Ohman, M. D., Goericke, R., Stukel, M. R., and Tsyrklevich, K. (2009). Lagrangian studies of phytoplankton growth and grazing relationships in a coastal upwelling ecosystem off Southern California. Prog. Oceanogr. 83, 208-216. doi: 10.1016/j.pocean.2009.07.026

Langmann, B. (2014). On the role of climate forcing by volcanic sulphate and volcanic ash. Adv. Meteorol. 2014:340123. doi: 10.1155/2014/340123

Langmann, B., Zaksek, K., and Hort, M. (2010b). Atmospheric deposition and removal of volcanic ash after the erruption of Kasatochi volcano: a regional model study. J. Geophys. Res. Atmos. 115, 27. doi: 10.1029/2009JD013298

Langmann, B., Zaksek, K., Hort, M., and Duggen, S. (2010a). Volcanic ash as fertiliser for the surface ocean. Atmos. Chem. Phys. 10, 3891-3899. doi: 10.5194/acp-10-3891-2010

Le Moigne, F. A. C., Moore, C. M., Sanders, R. J., Villa-Alfageme, M., Steigenberger, S., and Achterberg, E. P. (2014). Sequestration efficiency in the iron-limited North Atlantic: implications for iron supply mode to fertilized blooms. Geophys. Res. Lett. 41, 4619-4627. doi: 10.1002/2014gl060308

Lewis, M. R., Horne, E. P. W., Cullen, J. J., Oakey, N. S., and Platt, T. (1984). Turbulent motions may control phytoplankton photosynthesis in the upper ocean. Nature 311, 49-50. doi: 10.1038/311049a0

Li, F., Ginoux, P., and Ramaswamy, V. (2008). Distribution, transport, and deposition of mineral dust in the Southern Ocean and Antarctica: contribution of major sources. J. Geophys. Res. 113. doi: 10.1029/2007JD009190

Lin, I. I., Hu, C. M., Li, Y. H., Ho, T. Y., Fischer, T. P., Wong, G. T. F., et al. (2011). Fertilization potential of volcanic dust in the low-nutrient low-chlorophyll western North Pacific subtropical gyre: satellite evidence and laboratory study. Glob. Biogeochem. Cycle 25. doi: 10.1029/2009gb003758

Mackie, D. S., Boyd, P. W., McTainsh, G. H., Tindale, N. W., Westberry, T. K., and Hunter, K. A. (2008). Biogeochemistry of iron in Australian dust: from 
eolian uplift to marine uptake. Geochem. Geophys. Geosy 9. doi: 10.1029/2007gc 001813

Manning, A. C., and Keeling, R. F. (2006). Global oceanic and land biotic carbon sinks from the Scripps atmospheric oxygen flask sampling network. Tellus B 58, 95-116. doi: 10.1111/j.1600-0889.2006.00175.x

Mason, B. G., Pyle, D. M., and Oppenheimer, C. (2004). The size and frequency of the largest explosive eruptions on Earth. Bull.Volcanol. 66, 735-748. doi: 10.1007/s00445-004-0355-9

Mather, T. A., Pyle, D. M., and Oppenheimer, C. (2003). Tropospheric volcanic aerosol. Volcanism Earth's Atmos. 139, 189-212. doi: 10.1029/139GM12

Mélançon, J., Levasseur, M., Lizotte, M., Delmelle, P., Cullen, J., Hamme, R. C., et al. (2014). Early response of the northeast subarctic Pacific plankton assemblage to volcanic ash fertilization. Limnol. Oceanogr. 59, 55-67. doi: 10.4319/lo.2014.59.1.0055

Moore, J. K., and Abbott, M. R. (2000). Phytoplankton chlorophyll distributions and primary production in the Southern Ocean. J. Geophys. Res. 105, 28709-28722. doi: 10.1029/1999JC000043

Moore, C. M., Mills, M. M., Achterberg, E. P., Geider, R. J., LaRoche, J., Lucas, M. I., et al. (2009). Large-scale distribution of Atlantic nitrogen fixation controlled by iron availability. Nature Geoscience 2, 867-871. doi: 10.1038/ngeo667

Moore, C. M., Mills, M. M., Arrigo, K. R., Berman-Frank, I., Bopp, L., Boyd, P. W., et al. (2013). Processes and patterns of oceanic nutrient limitation. Nat. Geosci. 6, 701-710. doi: 10.1038/ngeo1765

Moore, C. M., Seeyave, S., Hickman, A. E., Allen, J. T., Lucas, M. I., Planquette, H., et al. (2007). Iron-light interactions during the CROZet natural iron bloom and EXport experiment (CROZEX) I: phytoplankton growth and photophysiology. Deep Sea Res. II 54, 2045-2065. doi: 10.1016/j.dsr2.2007.06.011

Morel, F. M. M., Milligan, A. J., and Saito, M. A. (2003), Marine bioinorganic chemistry: the role of trace metals in the ocean cycles of major nutrients. Treatise Geochem. 6, 113-143. doi: 10.1016/B0-08-043751-6/06108-9

Odermatt, D., Gitelson, A., Ernesto Brando, V., and Schaepman, M. (2012). Review of constituent retrieval in optically deep and complex waters from satellite imagery. Remote Sens. Environ. 118, 116-126. doi: 10.1016/j.rse.2011.11.013

Olgun, N., Duggen, S., Andronico, D., Kutterolf, S., Croot, P. L., Giammanco, S., et al. (2013a). Possible impacts of volcanic ash emissions of Mount Etna on the primary productivity in the oligotrophic Mediterranean Sea: results from nutrient-release experiments in seawater. Mar. Chem. 152, 32-42. doi: 10.1016/j.marchem.2013.04.004

Olgun, N., Duggen, S., Croot, P. L., Delmelle, P., Dietze, H., Schacht, U., et al. (2011). Surface ocean iron fertilization: the role of airborne volcanic ash from subduction zone and hot spot volcanoes and related iron fluxes into the Pacific Ocean. Glob. Biogeochem. Cycles 25. doi: 10.1029/2009GB003761

Olgun, N., Duggen, S., Langmann, B., Hort, M., Waythomas, C. F., Hoffmann, L., et al. (2013b). Geochemical evidence of oceanic iron fertilization by the Kasatochi volcanic eruption in 2008 and the potential impacts on Pacific sockeye salmon. Mar. Ecol. Prog. Ser. 488, 81-88. doi: 10.3354/meps10403

O'Malley, R. T., Behrenfeld, M. J., Westberry, T. K., Milligan, A. J., Reese, D. C., and Halsey, K. H. (2014). Improbability mapping: a metric for satellite-detection of submarine volcanic eruptions. Remote Sens. Environ. 140, 596-603. doi: 10.1016/j.rse.2013.09.029

Parekh, P., Follows, M. J., and Boyle, E. A. (2005). Decoupling of iron and phosphate in the global ocean. Glob. Biogeochem. Cycles 19. doi: $10.1029 / 2004 \mathrm{~GB} 002280$

Parsons, T. R., and Whitney, F. A. (2012). Did volcanic ash from Mt. Kasatoshi in 2008 contribute to a phenomenal increase in Fraser River sockeye salmon (Oncorhynchus nerka) in 2010? Fish. Oceanogr. 21, 374-377. doi: 10.1111/j.1365-2419.2012.00630.x

Platt, T., Bird, D. F., and Sathyendranath, S. (1991). Critical depth and marine primary production. Proc. R. Soc. B Biol. Sci. 246, 205-217. doi: 10.1098/rspb.1991.0146

Prata, A. J., and Prata, A. T. (2012). Eyjafjallajokull volcanic ash concentrations determined using Spin Enhanced Visible and Infrared Imager measurements. J. Geophys. Res. Atmos. 117. doi: 10.1029/2011jd016800

Raven, J. A., Evans, M. C. W., and Korb, R. E. (1999). The role of trace metals in photosynthetic electron transport in O-2-evolving organisms. Photosynth. Res. 60, 111-149. doi: 10.1023/A:1006282714942

Rivas, A. L., Dogliotti, A. I., and Gagliardini, D. A. (2006). Seasonal variability in satellite-measured surface chlorophyll in the Patagonian Shelf. Cont. Shelf Res. 26, 703-720. doi: 10.1016/j.csr.2006.01.013
Ryan-Keogh, T. J., Macey, A. I., Nielsdottir, M. C., Lucas, M. I., Steigenberger, S. S., Stinchcombe, M. C., et al. (2013). Spatial and temporal development of phytoplankton iron stress in relation to bloom dynamics in the high-latitude North Atlantic Ocean. Limnol. Oceanogr. 58, 533-545. doi: 10.4319/lo.2013.58. 2.0533

Sarmiento, J. L. (1993). Carbon-cycle-atmospheric $\mathrm{CO}_{2}$ stalled. Nature 365, 697-698. doi: 10.1038/365697a0

Sarmiento, J. L., and Gruber, N. (2006). Ocean Biogeochemical Dynamics. Princeton, NJ: Princeton University Press.

Sarmiento, J. L., Slater, R. D., Dunne, J., Gnanadesikan, A., and Hiscock, M. R. (2010). Efficiency of small scale carbon mitigation by patch iron fertilization. Biogeosciences 7, 3593-3624. doi: 10.5194/bg-7-3593-2010

Scasso, R. A., Corbella, H., and Tiberi, P. (1994). Sedimentological analysis of the tephra from the 12-15 August 1991 eruption of hudson volcano. Bull. Volcanol. 56, 121-132. doi: 10.1007/BF00304107

Schlosser, C., Klar, J. K., Wake, B. D., Snow, J. T., Honey, D. J., Woodward, E. M. S., et al. (2014). Seasonal ITCZ migration dynamically controls the location of the (sub)tropical Atlantic biogeochemical divide. Proc. Nat. Acad. Sci. U.S.A. 111, 1438-1442. doi: 10.1073/pnas.1318670111

Seftor, C. J., Hsu, N. C., Herman, J. R., Bhartia, P. K., Torres, O., Rose, W. I., et al. (1997). Detection of volcanic ash clouds from Nimbus $7 /$ total ozone mapping spectrometer. J. Geophys. Res. Atmos. 102, 16749-16759. doi: 10.1029/97JD00925

Self, S. (2006). The effects and consequences of very large explosive volcanic eruptions. Philos. Trans. Roy. Soc. A. 364, 2073-2097. doi: 10.1098/rsta.2006.1814

Self, S., Widdowson, M., Thordarson, T., and Jay, A. E. (2006). Volatile fluxes during flood basalt eruptions and potential effects on the global environment: a Deccan perspective. Earth Planet. Sci. Lett. 248, 518-532. doi: 10.1016/j.epsl.2006.05.041

Siegel, D. A., Doney, S. C., and Yoder, J. A. (2002). The North Atlantic spring phytoplankton bloom and Sverdrup's critical depth hypothesis. Science 296, 730-733. doi: $10.1126 /$ science.1069174

Sigman, D. M., and Boyle, E. A. (2000). Glacial/interglacial variations in atmospheric carbon dioxide. Nature 407, 859-869. doi: 10.1038/35038000

Sigman, D. M., Hain, M. P., and Haug, G. H. (2010). The polar ocean and glacial cycles in atmospheric $\mathrm{CO}_{2}$ concentration. Nature 466, 47-55. doi: 10.1038/nature09149

Smellie, J. L. (1999). The upper Cenozoic tephra record in the south polar region: a review. Glob. Planet. Change 21, 51-70. doi: 10.1016/S0921-8181(99)00007-7

Smetacek, V., Klaas, C., Strass, V. H., Assmy, P., Montresor, M., Cisewski, B., et al. (2012). Deep carbon export from a Southern Ocean iron-fertilized diatom bloom. Nature 487, 313-319. doi: 10.1038/nature11229

Snyder, W. A., Arnone, R. A., Davis, C. O., Goode, W., Gould, R. W., Ladner, S., et al. (2008). Optical scattering and backscattering by organic and inorganic particulates in US coastal waters. Appl. Optics 47, 666-677. doi: 10.1364/AO.47.000666

Spirakis, C. S. (1991). Iron fertilization with volcanic ash? EOS, Trans. Am. Geophys. Union 72, 525. doi: 10.1029/90EO00370

Strickland, J. D. H. (1960). Measuring the production of marine phytoplankton. Bull. Fish. Res. Bd Can. 122, 1-172.

Stefánsdóttir, M. B., and Gíslason, S. R. (2005). The erosion and suspended matter/seawater interaction during and after the 1996 outburst flood from the Vatnajökull Glacier, Iceland. Earth Planet. Sci. Lett. 237, 433-452. doi: 10.1016/j.epsl.2005.07.002

Stramski, D., Babin, M., and Wozniak, S. B. (2007). Variations in the optical properties of terrigenous mineral-rich particulate matter suspended in seawater. Limnol. Oceanogr. 52, 2418-2433. doi: 10.4319/lo.2007.52.6.2418

Sullivan, J. M., Twardowski, M. S., Ronald, J., Zaneveld, V., and Moore, C. (2013). "Measuring optical backscattering in water," in Light Scattering Reviews 7, ed A. A. Kokhanovsky (Springer: Berlin; Heidelberg), 189-224.

Sunda, W. G. (2012). Feedback interactions between trace metal nutrients and phytoplankton in the ocean. Front. Microbiol. 3. doi: 10.3389/Fmicb.2012.00204 Sverdrup, H. U. (1953). On conditions for the vernal blooming of phytoplankton. J. Cons. Int. Explor. Mer. 18, 287-295. doi: 10.1093/icesjms/18.3.287

Taylor, J. R., and Ferrari, R. (2011). Shutdown of turbulent convection as a new criterion for the onset of spring phytoplankton blooms. Limnol Oceanogr. 56, 2293-2307. doi: 10.4319/lo.2011.56.6.2293

Torres, O., Tanskanen, A., Veihelmann, B., Ahn, C., Braak, R., Bhartia, P. K., et al. (2007). Aerosols and surface UV products from Ozone Monitoring Instrument observations: an overview. J. Geophys. Res. Atmos. 112. doi: 10.1029/2007jd008809 
Trusdell, F. A., Moore, R. B., Sako, M., White, R. A., Koyanagi, S. K., Chong, R., et al. (2005). The 2003 eruption of Anatahan Volcano, Commonwealth of the Northern Mariana Islands: chronology, volcanology, and deformation. J. Volcanol. Geother. Res., 146, 184-207. doi: 10.1016/j.jvolgeores.2004. 12.010

Tsuda, A., Takeda, S., Saito, H., Nishioka, J., Nojiri, Y., Kudo, I., et al. (2003). A mesoscale iron enrichment in the western Subarctic Pacific induces a large centric diatom bloom. Science 300, 958-961. doi: 10.1126/science. 1082000

Tupper, A., Davey, J., Stewart, P., Stunder, B., Servranckx, R., and Prata, F. (2006). Aircraft encounters with volcanic clouds over Micronesia, Oceania, 2002-03. Aust. Meteorol. Mag. 55, 289-299.

Twardowski, M. S., Sullivan, J. M., Donaghay, P. L., and Zaneveld, J. R. V. (1999). Microscale quantification of the absorption by dissolved and particulate material in coastal waters with an ac-9. J. Atmos. Oceanic Technol. 16, 691-707.

Twining, B. S., and Baines, S. B. (2013). The trace metal composition of marine phytoplankton. Annu. Rev. Mar. Sci. 5, 191-215. doi: 10.1146/annurev-marine121211-172322

Uematsu, M., Toratani, M., Kajino, M., Narita, Y., Senga, Y., and Kimoto, T. (2004). Enhancement of primary productivity in the western North Pacific caused by the eruption of the Miyake-jima Volcano. Geophys. Res. Lett. 31. doi: $10.1029 / 2003 \mathrm{gl018790}$

Watson, A. J. (1997). Volcanic iron, $\mathrm{CO}_{2}$, ocean productivity and climate. Nature 385, 587-588. doi: 10.1038/385587b0

Watson, A. J., Bakker, D. C. E., Ridgwell, A. J., Boyd, P. W., and Law, C. S. (2000). Effect of iron supply on Southern Ocean $\mathrm{CO}_{2}$ uptake and implications for glacial atmospheric $\mathrm{CO}_{2}$. Nature 407, 730-733. doi: 10.1038/35037561

Watt, S. F. L., Pyle, D. M., and Mather, T. A. (2013). The volcanic response to deglaciation: evidence from glaciated arcs and a reassessment of global eruption records. Earth Sci. Rev. 122, 77-102. doi: 10.1016/j.earscirev.2013. 03.007

Watt, S. F. L., Pyle, D. M., Mather, T. A., Martin, R. S., and Matthews, N. E. (2009). Fallout and distribution of volcanic ash over Argentina following the May 2008 explosive eruption of Chaiten, Chile. J. Geophys. Res. Sol. Ea. 114. doi: $10.1029 / 2008$ jb006219

Webster, H. N., Thomson, D. J., Johnson, B. T., Heard, I. P. C., Turnbull, K., Marenco, F., et al. (2012). Operational prediction of ash concentrations in the distal volcanic cloud from the 2010 Eyjafjallajokull eruption. J. Geophys. Res.-Atmos. 117. doi: 10.1029/2011jd016790
Westberry, T. K., Behrenfeld, M. J., Milligan, A. J., and Doney, S. C. (2013). Retrospective satellite ocean color analysis of purposeful and natural ocean iron fertilization. Deep Sea Res. I 73, 1-16. doi: 10.1016/j.dsr.2012.11.010

Westberry, T. K., Siegel, D. A., and Subramaniam, A. (2005). An improved biooptical model for the remote sensing of Trichodesmium spp. blooms. J. Geophys. Res. Oceans 110. doi: 10.1029/2004jc002517

Wilson, T. M., Cole, J. W., Stewart, C., Cronin, S. J., and Johnston, D. M. (2011). Ash storms: impacts of wind-remobilised volcanic ash on rural communities and agriculture following the 1991 Hudson eruption, southern Patagonia, Chile. Bull. Volcanol. 73, 223-239. doi: 10.1007/s00445-010-0396-1

Wozniak, S. B., and Stramski, D. (2004). Modeling the optical properties of mineral particles suspended in seawater and their influence on ocean reflectance and chlorophyll estimation from remote sensing algorithms. Appl. Optics 43, 3489-3503. doi: 10.1364/AO.43.003489

Young, R. W., Carder, K. L., Betzer, P. R., Costello, D. K., Duce, R. A., DiTullio, G. R., et al. (1991). Atmospheric iron inputs and primary productivity: phytoplankton responses in the North Pacific. Glob. Biogeochem. Cycls 5, 119-134. doi: 10.1029/91GB00927

Zhang, X. D., Hu, L. B., and He, M. X. (2009). Scattering by pure seawater: effect of salinity. Opt. Express 17, 5698-5710. doi: 10.1364/OE.17.005698

Conflict of Interest Statement: The authors declare that the research was conducted in the absence of any commercial or financial relationships that could be construed as a potential conflict of interest.

Received: 10 November 2014; accepted: 09 February 2015; published online: 03 March 2015.

Citation: Browning TJ, Stone K, Bouman HA, Mather TA, Pyle DM, Moore CM and Martinez-Vicente V (2015) Volcanic ash supply to the surface ocean-remote sensing of biological responses and their wider biogeochemical significance. Front. Mar. Sci. 2:14. doi: 10.3389/fmars.2015.00014

This article was submitted to Marine Biogeochemistry, a section of the journal Frontiers in Marine Science.

Copyright (C) 2015 Browning, Stone, Bouman, Mather, Pyle, Moore and MartinezVicente. This is an open-access article distributed under the terms of the Creative Commons Attribution License (CC BY). The use, distribution or reproduction in other forums is permitted, provided the original author(s) or licensor are credited and that the original publication in this journal is cited, in accordance with accepted academic practice. No use, distribution or reproduction is permitted which does not comply with these terms. 